\title{
The Role of Bank Advisors in Mergers and Acquisitions
}

\author{
Linda Allen \\ Zicklin School of Business \\ Baruch College, City University of New York \\ Julapa Jagtiani \\ Supervision and Regulation \\ Federal Reserve Bank of Chicago \\ Stavros Peristiani \\ Capital Markets Function \\ Federal Reserve Bank of New York \\ Anthony Saunders \\ Stern School of Business \\ New York University
}

Current Draft: December 2001.

Keywords: Relationship banking, investment bank advisors, commercial bank advisors, certification effect, conflict of interest effect, mergers, acquisitions.

JEL Classification: G21

Address correspondence to: Linda Allen, Baruch College, 17 Lexington Avenue, Box 10-225, New York, New York 10010, Linda_Allen@baruch.cuny.edu.

An earlier version of this paper was presented at the 2000 American Finance Association meetings in Boston. The authors thank Anup Agrawal, Kobi Boudoukh, Mark Carey, David Feldman, Iftekhar Hasan, Randy Heron, William Curt Hunter, John McConnell, Jim Nelson, William Lang, and Jacob Paroush for their helpful comments. The authors gratefully acknowledge the support of Cathy Lemieux, and research assistance of Gulcin Afres, Sreedhar Bharath, Danny Chang, Yonca Ertimur, Gijoon Hong, Victoria Ivashina, Ahmet Karagozoglu, Elena Smirnova, Anand Srinivasan, and Jack Wozek. The opinions expressed in this paper are those of the authors, and do not necessarily represent those of the Federal Reserve Banks or the Federal Reserve System. Finally, the authors would like to thank two anonymous referees and the editor Mark Flannery for their helpful comments. 


\title{
The Role of Bank Advisors in Mergers and Acquisitions
}

\begin{abstract}
$\underline{\text { Abstract }}$
This paper looks at the role of commercial banks and investment banks as financial advisors. Unlike some areas of investment banking, commercial banks have always been allowed to compete directly with traditional investment banks in this area. In their role as lenders and advisors, banks can be viewed as serving a certification function. However, banks acting as both lenders and advisors face a potential conflict of interest that may mitigate or offset any certification effect. Overall, we find evidence of the certification effect for target firms, but conflicts of interest for acquirers.

In particular, the target earns higher abnormal returns when the target's own bank certifies the (more informationally opaque) target's value to the acquirer. In contrast, we find no certification role for acquirers. This may be due to two reasons. First, certification plays less of a role for acquirers because it is the target firm that must be priced in a merger. Second, acquirers predominantly utilize commercial bank advisors in order to obtain access to bank loans that may be used to finance the post-merger transition period. Thus, we find that acquirers tend to choose their own banks (those with prior lending relationships to the acquirer) as advisors in mergers. However, this choice weakens any certification effect and creates a potential conflict of interest because the acquirer's advisor negotiates the terms of both the merger transaction and future loan commitments. Moreover, the advisor's merger advice may be distorted by considerations related to the bank's credit exposure resulting from both past and future lending activity. The market prices these conflicts of interest; we find significantly negative abnormal returns for bank advisors when they advise their own loan customers in acquiring other firms.
\end{abstract}




\section{The Role of Bank Advisors in Mergers and Acquisitions}

\section{Introduction}

Financial intermediaries are specialists in information production and processing. As advisors to both targets and acquirers, financial institutions utilize their information gathering expertise to ascertain the reservation price of the merger counterparty, the potential for synergistic gains, as well as the risks of the transaction.

Commercial banks may be well positioned to offer these services if they have established lending and other customer relationships with either party to a merger. During the course of a long-term customer relationship, a commercial bank obtains private information about a firm's cash flows, financial resources, and other exposures that can be useful in estimating the future prospects of a proposed merger. Indeed, if the role of the financial advisor in a merger is to mobilize information, then commercial banks - especially those with prior lending relationships potentially have a comparative advantage over investment banks in advising their customers particularly since, until very recently, investment banks did not make commercial loans. ${ }^{\text {T }}$ The banking literature (see Chan, Greenbaum, and Thakor (1986) for example) suggests that information generated in the course of a banking relationship may be reusable and therefore transferable. This transfer is feasible because while SEC regulations and the U.S. bankruptcy code prohibit the transfer of information from an investment bank subsidiary to a related

\footnotetext{
${ }^{1}$ Investment banks may grant "bridge loans" particularly in the context of facilitating a merger. Since these loans are of short duration, granted for very specific purposes, they are not likely to produce the private information obtained by a commercial bank in the course of a long-term, generalized business lending relationship. We exclude the consideration of these less informative "bridge loans" from our analysis. Michaely and Womack (1999) consider another potential conflicts of interest for investment bank advisor stemming from the relationship between analyst recommendations and underwriting activity. Before the repeal of the Glass Steagall Act, this conflict did not apply to commercial banks because they could not offer full service investment banking services that included investment advice. See the 1994 Supreme Court decision involving Citicorp.
} 
commercial bank subsidiary, there are no restrictions on the reuse of information obtained in the course of a standard banking relationship (e.g., on information flows from the bank's lending department to the investment bank).

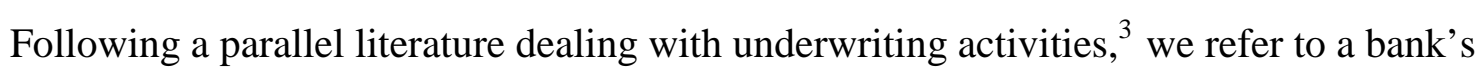
ability to mobilize private information about a customer, and to use this information in supplying services such as merger advice to the customer, as the certification effect. Investment banks may also be privy to private information obtained, for example, in the course of underwriting activities. However, underwriting episodes are discrete and intermittent, corresponding to the relatively short time period surrounding the issue registration, offering period, and after-market support period. In contrast, commercial bank lending and other relationships are often long standing and continuous, requiring the ongoing monitoring of the firm's activities. All else being equal, we would expect that the selection and use of a commercial bank advisor in an M\&A transaction provides a higher certification effect than that provided by traditional investment banks.

There are, however, countervailing influences to the certification effect that may limit the effectiveness of commercial banks in providing merger advisory services. This is especially so if the bank advisor is faced with one or more conflicts of interest. For example, the target may have financial problems known privately only to its lenders (such as the major bank lender), or an acquirer may be financially weak to the private knowledge of the banker, and its ability to

\footnotetext{
${ }^{2}$ In June 1997, the courts ruled in ADP v. Chase Manhattan Bank that "a bank has no per se obligation to refrain from such participation" as advisor to an acquirer (Western Resources) in a hostile attempt to take over Chase's banking customer ADP Ltd. (Michael Bender, Investment Dealers’ Digest, June 30, 1997, p. 9-10.)

${ }^{3}$ See Puri (1994, 1996), Ang and Richardson (1994), Kroszner and Rajan (1994), Gande, Puri, Saunders, and Walter (1997), and Hebb (1999).

${ }^{4}$ See Fama (1985), Diamond (1991), and Rajan (1992) and the special issue of the Journal of Financial Intermediation (2000) for a discussion of the information generated in the course of relationship intermediation.
} 
survive and pay off its bank debt may be enhanced through the acquisition of a target with a sizable free cash flow. In these situations, the commercial bank's certification may not be credible because of the bank's self-interest in assuring the completion of the merger. This conflict of interest effect is likely to be exacerbated in the case of hostile takeovers. For example, if a commercial bank customer (as a target) objects to an acquisition, perhaps because of entrenched managers' fear of loss of control, then the commercial bank may be either unable or unwilling to utilize fully its private information in advising a potential acquirer for fear of the loss of future commercial banking business should the merger actually fail to be completed. Moreover, a commercial bank may be able to attract merger advisory business only on the condition that bank loans are made available to the merger counterparties, or alternatively, a bank may be more willing to advise a firm to undertake an acquisition if it believes it can earn large fees from financing the merger through its lending department. These may constitute conflicts of interest to the extent that the bank's advice is skewed by the bank's concern about the profit it earns from its lending as well as is merger advisory services.

The aim of this paper is to examine, empirically, whether the certification effect dominates the conflict of interest effect in the market for mergers and acquisitions advice, and to measure the relative effects on targets and acquirers of commercial bank participation as merger advisors. We compare stock market (abnormal) returns to acquirers and targets on merger deals where commercial banks have been the advisors relative to deals advised by a control group of

\footnotetext{
${ }^{5}$ The potential for conflicts of interest was raised in the case of Lehman Brothers, the advisor for Dynegy, the erstwhile acquirer of Enron Corporation in the context of repayment of a $\$ 179$ million swap transaction.

“...Lehman's dual agenda - pursuing a possible merger and in the same set of talks its own repayment - presents a possible conflict of interest, some investment-banking specialists say. That is because Lehman's interest in seeking repayment during the talks could have complicated Dynegy's ability to strike a deal....Of course, Lehman isn't the only firm acting in dual roles in Enron matters. Until recently, Citigroup Inc. and JP Morgan Chase \& Co. had been acting as both merger advisors and lenders to Enron. Now that Enron has sought bankruptcy-law protection from creditors, those two banking firms have been precluded from serving as advisors because of their creditor status."
} 
top tier investment banks (Goldman Sachs, Credit Suisse First Boston, Salomon Brothers, and Morgan Stanley Dean Witter) as well as a control group of mid tier investment banks (Bear Stearns, Lehman Brothers, PaineWebber and Donaldson, Lufkin and Jenrette). ${ }^{\text {G }}$ In the investment bank control groups, there is no commercial bank advisor participation at all.

When we control for prior banking relationships, we find evidence of a net certification effect for commercial banks. However, this effect holds only for commercial banks' role as M\&A advisors to targets. Target firms are typically smaller and more informationally opaque firms than acquiring firms. Banks that advise target firms can reuse information obtained in the course of a prior banking relationship by certifying the value of the merger (e.g., whether the price the acquirer offers to pay for the target is appropriate). The target bank's private information about the target firm is particularly valuable because of information asymmetries that make it difficult to certify the value of the target, and because it is the target firm that must be priced in a merger. However, this certification effect is likely to be reduced if the target bank advises the acquirer, since the target's bank may be reluctant to reveal bad information about the target to the acquirer for fear that if the deal is not completed, the target will penalize the bank with the loss of its banking business. Indeed, we find that acquirer's abnormal returns are either negative or statistically insignificant both when the target's bank and the acquirer's bank advises the acquirer, and that the use of commercial bank advisors with prior banking relationships has no significant impact on acquirer abnormal returns.

Smith (2001), p. C1, C11.

${ }^{6}$ The identities of the top tier and mid tier investment banks were obtained from Merger Advisory League Tables compiled by Thomson Financial and Garner and Kale (2001).

${ }^{7}$ In the wake of the passage of the Gramm Leach Bliley Act of 1999, financial holding companies (FHC) can be formulated by merging commercial banks and investment banks. For the purposes of this study, we consider any financial institution with a substantial commercial bank subsidiary to be a "commercial bank." Thus, we classify Citigroup (an FHC) as a commercial bank. 
Acquirers are not indifferent to commercial bank relationships, however. We find that if an acquiring firm has had a prior lending relationship with a commercial bank, then the acquirer is more likely to utilize that bank as its financial advisor. This is not because of an informational certification effect, but rather due to the bank's implicit (or explicit) promise of bank loans to finance the merger transaction and post-merger transition. Thus, it is the combination of merger advisory services and access to bank credit that is the focus of acquirer concerns in choosing their financial advisor. This creates a potential conflict of interest for the bank advisors. Indeed, we find that bank advisor abnormal returns are significantly reduced when banks offer these "package deals" that combine loan commitments with merger advisory services.

Section 2 briefly reviews the extensive literature on mergers and acquisitions. In Section 3, we describe our methodology. The database is described in Section 4 and the empirical results are discussed in Section 5. Section 6 concludes.

\section{The Literature}

Several branches of the literature are relevant to our study. First, there is the literature concerning the role of advisors in creating (or destroying) value in mergers and acquisitions. Second, there is the literature comparing the role of investment banks with that of commercial banks in undertaking "investment banking-type activities." Third, there is the literature investigating the value of mergers and acquisitions per se. Rather than providing an exhaustive review, we examine selected papers' relevance to the issue at hand.

\subsection{Do Advisors Add Value in Mergers?}

There is a literature examining whether advisors add value to a merger. Bowers and Miller (1990) examine the relationship between an acquiring firm's stock returns and the choice 
of investment bank to determine whether first-tier investment banks generate better deals in terms of value creation. They classified the following as first-tier investment banks: First Boston, Goldman Sachs, Merrill Lynch, Morgan Stanley, and Salomon Brothers. They report that total wealth gains are larger when either the target or acquirer uses a first-tier investment bank. The results suggest the importance of the advisor's credibility (reputation) in acquisitions. Hunter and Walker (1990) find that merger gains relate positively to investment banking fees and other proxies for investment banker effort. However, McLaughlin $(1990,1992)$ reports that some incentive features of investment banking contracts can create conflicts of interest between an investment bank and its clients, suggesting the importance of a potential for a conflict of interest between advisors and clients in mergers and acquisitions.

Servaes and Zenner (1996) compare acquisitions that were completed in-house versus those that use investment bank advisors. They find that an investment bank is used in more complex transactions with asymmetric information, documenting the importance of the information collection process in mergers and acquisitions.

Building on the theoretical model in James (1992), Saunders and Srinivasan (2001) finds that merger advisory fees include a relationship premium that is consistent with the existence of switching costs borne by acquirers when they hire new advisors with whom they had no prior relationship. If merger fees are set competitively, an explanation for this relationship premium is a certification effect, whereby rents are paid to banks with superior information obtained in the course of a prior relationship. Saunders and Srinivasan (2001) also find that top tier advisors charge higher fees than lower tier investment banks, and that acquirers pay a relationship premium in merger fees that is highest for top tier advisors. Although Rau (2000) finds no impact of advisors on acquirer abnormal returns, he shows a positive relationship between 
investment bank market share and fees and deal completion rates. That is, top-tier investment bank advisors create value by increasing the likelihood that the deal will be completed.

These previous studies examine only those mergers advised by investment banks. We extend the literature by examining whether a commercial bank's greater potential net certification ability contributes value to a merger or acquisition beyond that provided by traditional investment banks.

\subsection{Investment vs. Commercial Banks Providing Investment Banking Services}

The debate regarding financial services modernization and the elimination of the GlassSteagall Act has fueled a number of academic studies contrasting the roles of investment banks to commercial banks. Similar in flavor, if not in substance, to our study is the literature on the potential for conflicts of interest in securities underwriting.

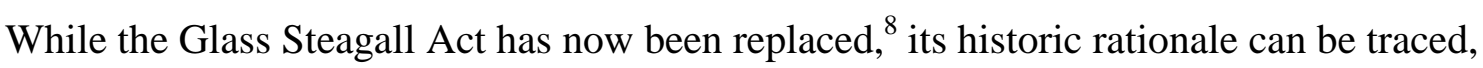
in part, to concerns that commercial bank underwriters have conflicts of interest that will encourage the public issuance of securities in order to reduce their own poor quality loan exposures. In general, empirical evidence has not supported the existence of such a conflict of interest. Kroszner and Rajan (1994), Ang and Richardson (1994), and Puri (1996), among others, ${ }_{\text {find }}$ that the debt securities underwritten by commercial banks prior to Glass-Steagall's passage in 1933, were less likely to default than those underwritten by investment banks. In addition, yields tended to be lower and the credit quality higher for commercial bankunderwritten issues than for issues underwritten by investment banks. Moreover, no significant difference was found in the performance of the equities underwritten by investment banks during

\footnotetext{
${ }^{8}$ The Gramm Leach Bliley Act of 1999 essentially eliminates the major barriers among banking, securities, and insurance activities.
} 
the 1920s as opposed to commercial bank affiliates. Indeed, Puri $(1994,1996)$ finds evidence of a certification role for commercial banks as they enhance their reputations by reusing private information obtained in the course of banking relationships.

More modern (post-1990) evidence based on the limited debt underwriting powers for banks in Gande, Puri, Saunders, and Walter (1997), and equity underwriting powers in Hebb (1999) have tended to confirm the earlier evidence of a net certification effect for banks.

Although the Glass-Steagall Act did not prohibit banks from advising in mergers and acquisitions cases, the relevance of certification effects and of potential conflicts of interest, in the area of merger advisement, is the central empirical question being investigated in this paper.

\subsection{The Value of Mergers and Acquisitions}

Out of the exhaustive empirical literature on mergers and acquisitions, one result is highly robust. This is the empirical finding that target firms tend to experience positive abnormal returns upon merger announcements while acquirers post zero or negative abnormal returns. 10 Thus, targets appear to obtain most of the expected merger and acquisition gains. 1

Target gains stem from many sources. The corporate control hypothesis, studied by Harris and Raviv (1988), Stulz (1988), Amihud, Lev, and Travlos (1990), and Franks and Mayer (1996) links merger gains to the reduction in agency costs in the market for corporate control. The market power hypothesis stipulates that mergers enhance the competitive position of the

\footnotetext{
${ }^{9}$ See Benston (1990) as well as the citations in footnote 2.

${ }^{10}$ Bank mergers are an exception to this generalization. For example, James and Weir (1987) find significant positive abnormal returns for acquirers in bank mergers. See Palia (1994) for a survey of empirical studies on bank mergers.

11 Existing literature on the post-merger performance of acquiring firms, however, is divided. Agrawal, Jaffe, and Mandelker (1992) find that stockholders of acquiring firms suffer a 10\% loss over the 5-year post-merger period, and that neither the firm size effect nor the beta estimation problems are the cause of the negative post-merger returns. In contrast, Healy, Palepu, and Ruback (1992) find significant post-merger increases in operating cash flow returns. Linn and Switzer (2001) show that post-merger performance is better for cash financed deals.
} 
target [see Beatty et al. (1987) and Berger and Humphrey (1992)]. Berkovitch and Narayanan (1993) find evidence of the synergy motive in mergers and acquisitions. Hubbard and Palia (1999) find synergistic gains to targets in the creation of internal capital markets within conglomerates created by a program of diversifying mergers and acquisitions.

Whereas targets must receive some expectation of gain in order to win the approval of their target shareholders for any merger, those acquirer firm managers, who are unconstrained by pressure from value maximizing shareholders, may embark on acquisitions that offer no ex ante gain to stockholders. The managerial risk diversification hypothesis [see Amihud and Lev (1981), Amihud and Kamin (1979), and Lloyd, Hand and Modani (1987)] postulates that acquiring firm managers undertake (value reducing) mergers in order to reduce their undiversifiable human capital investment in their firm. Evidence of this is shown in Amihud, Kamin, and Ronen (1983). In a European context, Cybo-Ottone and Murgia (2000) show that diversifying mergers are value reducing, whereas focusing mergers are value enhancing. In the winner's curse or hubris hypothesis, overly optimistic acquirers overbid for targets. For example, Roll (1986) shows that acquirers who overestimate the value of the target are more likely to successfully complete a merger, resulting in a decline in the acquirer's value to stockholders.

The question, unexamined prior to this paper, is how the choice of financial advisor impacts the distribution of gains between target and acquirer upon the announcement of a merger.

\section{Empirical Methodology}

\subsection{Computing Abnormal Returns for Targets and Acquirers}


To investigate the net certification role of commercial banks as merger and acquisition advisors, we compute standardized cumulative abnormal returns (SCAR) to both targets and acquirers for a three-day window around the merger announcement date. Our estimates of 3-day abnormal returns, denoted $(-1,+1)$, include both the day of the merger announcement, as well as one day before and after. ${ }^{\square}$ We test for the explanatory power of the advisor's identity, controlling for other deal-specific factors. Even if the advisor's identity is not publicly revealed on the merger announcement date, the market would reward well-designed and attractivelypriced deals without necessarily knowing the advisor's role in producing the positive results.

Our estimation of target and acquirer abnormal returns follows well established procedures used in other event studies, such as Fama, Fisher, Jensen, and Roll (1969), Bradley, Desai, and Kim (1988), and Stulz, Walking and Song (1990). We estimate a single-index model using CRSP daily stock returns to compute expected (benchmark) returns. Specifically, market model parameters for both target and acquiring firms are estimated using 190 trading days of daily returns data beginning 250 days and ending 60 days before the first announcement of the merger. 13

\subsection{Controlling for the Identity of the Advisor, Characteristics of Targets and}

\section{Acquirers, and Deal-Specific Factors}

The identity of the bank advisor and the credit/lending relationship ${ }^{14}$ between the bank advisor and target and/or acquirer is defined by four different dummy variables: $T B \_B T$ takes on

\footnotetext{
${ }^{12}$ We present our results using the standard $(-1,+1)$ window, although analogous results were obtained when using a wider $(-5,+5)$ window.

${ }^{13} \mathrm{We}$ used the first announcement date for multiple or revised bid deals. If daily return data were unavailable for the full 250 days prior to merger announcement, then the normal estimation period was less than the full 190 days.

${ }^{14} \mathrm{~A}$ credit/lending relationship exists if the bank has made loans to either merger counterparty at some date prior to the merger announcement date. The precise empirical definition of a credit/lending relationship is presented in Section 4.
} 
the value 1 if the target's advisor is a commercial bank and if the bank advisor had a prior relationship with the target; $T B \_B A$ takes on the value 1 if the target's advisor is a commercial bank and if the bank advisor had a prior relationship with the acquirer; $A B \_B T$ takes on the value 1 if the acquirer's advisor is a commercial bank and if the bank advisor had a prior relationship with the target; $A B \_B A$ takes on the value 1 if the acquirer's advisor is a commercial bank and if the bank advisor had a prior relationship with the acquirer. ${ }^{1.5}$ We distinguish between deals advised by top tier and mid tier investment banks and those advised by commercial banks through the use of the variable $D U M B A N K$, which is a dummy variable that equals 1 for all commercial bank advised deals and 0 for deals advised by the investment bank control group. The dummy variable TOPTIER denotes all targets and acquirers in our top tier investment bank control group that obtain advice from at least one top-tier investment bank (Goldman Sachs, Credit Suisse First Boston, Salomon Brothers, or Morgan Stanley Dean Witter). ${ }^{16}$ The dummy variable MIDTIER indicates those deals using only mid tier investment bank advisors such as Bear Stearns, Lehman Brothers PaineWebber and Donaldson Lufkin and Jenrette (during the time periods when these firms were independent). There were no commercial bank advisors at all in the investment bank advisor control groups.

In our regression analysis, we also control for deal specific variables not related to the identity and relationship of the advisors to targets and acquirers. Several control factors are incorporated into the model to capture the impact on abnormal returns resulting from characteristics of the target, the acquirer, or the offer. These control factors are discussed next.

\subsubsection{Control Factors}

\footnotetext{
${ }^{15}$ More than one of these variables could take on the value of one for any given observation. Thus, if $T B \_B T=$ $T B \_B A=1$ then the target advisor has had prior lending relationships with both target and acquirer.
} 
A robust result in the merger literature is that announcement returns to bidding firms who make cash offers are higher than when stock offers are made [see Travlos (1987)], since a bidder with private information about the value of its own assets offers stock when its shares are overvalued by target shareholders. Recognizing this adverse selection effect, target shareholders reduce their estimate of a bidder's value. Thus, without some other benefit to target stockholders in receiving stock rather than cash as a means of payment, a "lemons problem" arises for stock offers. ${ }^{1.7}$ The means of payment in a merger and acquisition is incorporated in our model through the variable PCTCASH (a variable that reflects the percentage of the deal value that is paid for in cash). Previous studies suggest a positive coefficient on the PCTCASH variable.

Stulz, Walking, and Song (1990) find that the relationship between a target's abnormal return and the target firm's ownership structure depends on the relative power of the bidder to successfully complete the acquisition without competition from other bidders (i.e., the stronger the bidder -- in terms of either lower target management's ownership stake, larger bidder ownership stake, or fewer bidders -- the lower the target's abnormal returns). Our empirical proxy variable for this effect takes the form of $B V P R E M$, which is defined as the initial offer price for the target over the target's book value of equity. Since a multiple-bidder auction for the target tends to offer a relatively large initial acquisition premium, we anticipate a direct relationship between $B V P R E M$ and target abnormal returns. This relationship is also consistent with Roll's (1986) hubris hypothesis. Following Doukas and Travlos (1988) and Kang (1993), who find evidence of positive abnormal returns for international acquisitions, we use a one-zero dummy variable denoting whether the deal is a cross-border merger or not (CROSS). Because

\footnotetext{
16 These investment banks were chosen to be consistent with Bowers and Miller (1990).

17 Brown and Ryngaert (1991) shows that taxes should also have important implications for the bidder's decision
} 
integration of larger targets into the acquiring firm is likely to generate agency cost reductions in value, we incorporate the control variable RELSIZE, measured as the ratio of the market value of equity for the target to the acquirer. Rajan, Servaes, and Zingales (2000) show that as a firm becomes more diverse (measured empirically as the deviation in size across all firm subdivisions) internal capital may be misallocated within the firm due to inefficiencies as a result of the battle between competing divisions for scarce capital resources. Since integration of a relatively large target in the course of a merger is likely to accentuate the internal power struggle over capital allocation, we expect a negative relationship between RELSIZE and abnormal returns.

Cotter and Zenner (1994) document that abnormal returns are lower for hostile compared to friendly mergers, controlling for size (market value of equity), ownership factors, and other characteristics of the offer (e.g., whether there are multiple bidders and whether the target has a golden parachute). Consequently, we incorporate the variable ATTITUDE (hostile, neutral, or friendly) into our estimation. We also check for robustness using CLOSE (a dummy variable denoting whether or not the target is closely held), MGMT (denoting whether the target's management participated in the merger), and PROTECT (denoting whether the target firm had protective mechanisms such as golden parachutes or poison pills). The latter variable is also suggested by the findings of Comment and Schwert (1995) who showed higher takeover premiums for firms with anti-takeover provisions in place.

Dummy variables indicating the motive for the acquisition are included based on the findings of Berkovitch and Narayanan (1993), who suggest that synergy is the primary motive in those takeovers with positive total gains to both targets and acquirers, and that agency conflicts are the primary motive in takeovers with negative gains to both targets and acquirers. Targets may also be 
valuable because of their high profitability (proxied by TPROFIT), growth rate (proxied by TGROWTH), or Tobin's q (measured as the market price to book value of the target firm, $T O B I N Q$ ).

We control for the target firm's leverage ratio using the variable TLEVER. Finally, annual (time) dummy variables are used to differentiate mergers announced in each year from 1995 to 2000 .

We estimate the following expressions for both targets and acquirers separately:

$$
\begin{gathered}
S C A R_{i}=f\left(T B \_B T, T B \_B A, A B \_B T, A B \_B A, D U M B A N K, B V P R E M, T G R O W T H,\right. \\
\text { TPROFIT, TLEVER, RELSIZE, DUMCASH, CROSS, ATTITUDE, YEAR }+\varepsilon_{i},
\end{gathered}
$$

where $S C A R_{i}$ is the 3 -day standardized cumulative abnormal return to target and acquiring firm $i$ and all control variables are as defined in Table 1.

\section{The Data}

Mergers and acquisitions data were obtained from the Thomson Financial Securities Data Corporation (SDC) database. All mergers and acquisitions involving U.S. target firms over the period January 1, 1995 through December 31, 2000 were identified. We excluded all mergers involving financial firms as either target or acquirer. We formed a subset of deals consisting of those merger transactions in which either side of the transaction (target or acquirer) or both list a commercial bank or its subsidiary as an advisor. ${ }^{19}$ We then conducted a Lexis/Nexis search on

\footnotetext{
${ }^{18}$ In order to examine other variables considered in the merger literature, we conducted robustness checks of our model. We incorporated a control variable TENDER denoting whether a tender offer had occurred, since it has been established that successful tender offers may increase target shareholder wealth [see Jensen and Ruback (1983)]. In addition to the control variable PCTCASH, discussed in Section 3.2.1, we focused on several other methods of financing mergers and acquisitions. These included SFC (a dummy variable indicating the issuance of common stock to finance the acquisition), SFCORP (a dummy variable indicating the use of internally generated funds), SFDEBT (a dummy variable indicating the use of debt), and $S W A P$ (a dummy variable denoting a stock swap). We also included an ownership variable, $B L O C K$, to denote block shareholdings, $M O E$ (an SDC-designation of "merger of equals") and the variable CASHFLOW to measure free cash flow (computed as cash assets divided by total assets). We included a dummy variable, $M E R G E R$, for completed target acquisitions (denoted by a value of 1 ) in contrast to partial acquisitions, spin-offs, or split-offs (all denoted as 0). Following Saunders and Srinivasan (2001), a variable FEES controlled for total fees paid by both target and acquirer as a percent of transaction value. None of these variables turned out to be statistically significant and we do not present them in our regression results presented in Section 5.2.

${ }^{19}$ Several commercial bank holding companies themselves acquired investment firms during the sample period. We
} 
each of the targets and acquirers to determine whether there was a prior banking relationship with any of the bank advisors. In this search, we examined SEC 10K, 10Q, and 8K filings, as well as annual reports, prospectuses, and other registered filings that dated back to January 1990 in order to determine whether the bank advisors had any prior credit/lending relationship with either of the parties to the merger. ${ }^{20}$ If the bank advisor was listed in any of the SEC filings of the merger parties, we recorded a bank relationship dummy variable of one. 21 If there was no mention of the bank advisor, but there was a description of other bank relationships, we recorded a bank relationship dummy variable of zero. ${ }^{22}$ If there was any ambiguity in defining the bank relationship for either the target or the acquirer, we recorded the relationship as missing. Using this procedure, we constructed the four dummy variables that distinguish among the four possible banking relationships: the target's bank advising the target $\left(T B \_B T\right)$, the acquirer's bank advising the target $\left(T B \_B A\right)$, the target's bank advising the acquirer $\left(A B \_B T\right)$, and the acquirer's bank advising the acquirer $\left(A B \_B A\right)$.

To fill in some of the missing bank relationships, we obtained data on loan syndications from Loan Pricing Corporation (LPC). If LPC showed that a bank advisor participated in a loan syndication in any capacity (i.e., as an agent, arranger, or participant) prior to the merger announcement date, then we recorded that as a prior banking relationship. The LPC database included description of the role of the lender, the origination date of the loan syndication, and the included acquisitions advised by the investment firm as acquisitions advised by commercial banks if the deal was announced after the commercial bank acquired the investment firm. For instance, in April 1997 Alex-Brown \& Company was acquired by Bankers Trust. Prior to that date, acquisitions advised by Alex-Brown were considered to be non-bank advised mergers. After that date, they were classified as bank advised mergers.

${ }^{20}$ Lexis/Nexis provides prospectuses and registration statements from April 1993 to the present only.

${ }^{21}$ Because the SEC does not require firms to reveal specific details about their banking relationships, we could not utilize more detailed data about the nature of the relationship. Data obtained from Loan Pricing Corporation contained more detailed descriptions of the lending relationship.

${ }^{22}$ We therefore avoided the problem of recording no relationship for companies that chose not to report any of their banking arrangements. 
purpose of the loan, among other descriptive variables. We use these variables to analyze the intensity of the lending relationship for the subset of deals that were included in the LPC database. ${ }^{23}$ We also used the more detailed LPC database to define the ACCESS indicator variable that takes on a value of 1 if the acquirer's bank is hired as an advisor and subsequently makes a loan to the acquirer up to one or two years after the merger announcement date.

Our sample includes only those firms whose shares were traded on either NYSE, AMEX, or Nasdaq. In order to obtain a non-merger period, with which to estimate abnormal returns, we utilized returns for a full year prior to the start of our merger sample period of January 1995 through December 2000. Thus, daily stock returns over the period January 1, 1994 through December 31, 2000 were obtained from CRSP. 24 We verified the SDC announcement date using the Wall Street Journal, and used the date in the Wall Street Journal whenever there was a discrepancy.

Next, we constructed a control sample of deals advised by (1) top tier investment banks, defined to be Goldman Sachs, Credit Suisse First Boston, Salomon Brothers, and Morgan Stanley Dean Witter and (2) mid tier investment banks, defined to be Bear Stearns, Lehman Brothers, PaineWebber, and Donaldson Lufkin and Jenrette (during the time periods when each of these firms was independent). Deals were included in the control sample only if there were no commercial bank advisors for either the target or the acquirer. When all financial mergers and non-publicly traded companies were excluded, we were left with 189 deals ${ }^{25}$ in the investment

\footnotetext{
${ }^{23}$ Although LPC focuses on syndicated loans, it also includes some private placements and underwritten debt. However, since the SEC filings consider all bank lending relationships, we used the LPC database to fill in the missing observations from the more comprehensive Lexis/Nexis.

${ }^{24}$ The CRSP Permanent Number was used to obtain a continuous series of stock return data even if company name, ticker, or CUSIP changed.

${ }^{25}$ There were 189 targets and 175 acquirers in the control sample. The difference in the number of observations stems from deals in which there was no advisor chosen by either the target or the acquirer.
} 
bank control sample.

Control variables were constructed from SDC, CRSP and COMPUSTAT. The tickers for each acquirer and target provided by SDC were matched with the CRSP permanent numbers in order to obtain daily return data and market capitalization values as of the deal announcement date. Wherever necessary, COMPUSTAT data were used to fill in the values of control variables such as TLEVER (target debt/equity ratios) and TPROFIT (target return on assets). A list of definitions of all control variables is shown in Table 1.

The overall sample (including investment banks and commercial banks as advisors) consists of 488 targets and 495 acquirers. ${ }^{26}$ Table 2 displays key descriptive statistics. 27 Targets (acquirers) hired bank advisors in $31.4 \%(34.3 \%)$ of the deals. Out of the total number of mergers, $36.8 \%$ of the target advisors had either prior banking relationships with the target $(22.5 \%)$ or the acquirer $(14.3 \%)$. Table 2 also shows that $27.9 \%$ of the acquirer advisors had prior banking relationships with either the target (12.9\%) or the acquirer (15\%). The control group of top tier and mid tier investment banks advised $38.7 \%$ of the targets and $35.4 \%$ of the acquirers. Most of the mergers in our sample (62.1\%) took place in the years $1998(23.6 \%)$ and $2000(38.5 \%) .28$ Finally, most deals (93.4\%) were classified by SDC as either friendly or neutral. However, average target abnormal returns were significantly (at the $10 \%$ level) higher for hostile deals (a mean abnormal return of 5.12\%) than for friendly/neutral deals (a mean of 3.32\%). 29

\footnotetext{
${ }^{26}$ There are more targets than acquiring firms because some acquirers are foreign firms that are not traded on either NYSE, AMEX, or Nasdaq. However, most foreign acquirers are traded on US stock exchanges. Excluding all foreign acquirers would have resulted in the loss of more than 100 observations. Thus, we control for cross border acquisitions in our analysis.

${ }^{27}$ Table 2, Panel C reports descriptive statistics for control variables. There were 684 observations in the merger database, but data availability on CRSP and Compustat limited our final sample to 488 targets and 495 acquirers.

${ }^{28}$ Although the Gramm-Leach-Bliley Act of 1999 (permitting investment banks to acquire commercial bank subsidiaries) took effect in March 2000, we find no impact on our results for the pre- versus the post-GLBA periods.

${ }^{29}$ We performed pairwise mean difference tests using both the pooled and Satterthwaite methods to control for the possibility of unequal variances. Whenever statistically significant, the results of pairwise mean difference tests are
} 


\section{Empirical Results}

Consistent with the literature to date, Table 2, Panel A shows that target abnormal returns are on average positive and statistically significant at the $1 \%$ level (averaging $3.38 \%$ ), whereas acquirer abnormal returns are either negative (on average $-0.31 \%$ significant at the $1 \%$ level) or insignificantly different from zero. In particular, the average 3 -day $(-1,+1)$ acquirer abnormal return of $-0.60 \%$ is significantly negative (at the $1 \%$ level) for deals advised by top tier investment banks, suggesting that some of the significantly positive gains to targets may come at the expense of acquirers. 30 In contrast, acquirer abnormal returns $(0.28 \%)$ for those deals advised by mid tier investment banks are significantly higher (at the $10 \%$ level) than for those deals advised by either top tier investment banks or commercial banks (3-day acquirer abnormal returns average $-0.35 \%$ ). This result is consistent with the results of Rau (2000) and Hunter and Jagtiani (2001) who find that top tier investment banks tend to advise acquirers to pay too much for target firms.

Table 2 Panel A also shows that target abnormal returns over the $(-1,+1)$ period are significantly (at the $1 \%$ level) positive for all bank advised deals, whereas acquirer abnormal returns tend to be either significantly negative or insignificantly different from zero.

Interestingly, acquirer returns are highest when the acquirer does not use any financial advisor (a mean of $0.21 \%$ which is significantly higher at the $5 \%$ level than the mean acquirer abnormal returns when the acquirer uses either a commercial bank or an investment bank as financial

reported in Table 2. The pair of means to be compared is marked with the same letter in the superscript of the standard error reported in Table 2. The significance level is denoted by a 1 (2) for the 5\% (10\%) levels.

${ }^{30}$ Acquirer abnormal returns are significantly lower (at the 5\% level) for those deals advised by top tier investment banks than for those deals advised by either mid tier investment banks or commercial banks which have an average abnormal return to the acquirer of $-0.19 \%$ (significant at the $10 \%$ level). This is consistent with Srinivasan (1999) who finds that acquirers pay top tier investment banks significantly higher fees for merger advice, thereby reducing acquirer abnormal returns. 
advisor). In contrast, the target's abnormal returns are reduced to a mean of $2.80 \%$ when the target does not hire a financial advisor. 1

\subsection{Target and Acquirer Abnormal Returns Without Controlling for Banking}

\section{Relationships}

The regressions presented in Table 3 examine the 3-day abnormal returns controlling for deal characteristics, but not controlling for the existence of prior banking relationships. Although we examine all the control variables listed in Table 1, we present the results for only the most consistently significant variables in Tables 3-5. These control variables can be divided into two groups: (1) Deal characteristics such as PCTCASH (the percentage of cash used to finance the merger), BVPREM (the premium of the price over the target's book value), ATTITUDE ( $=0$ if friendly or neutral, $=1$ if hostile $)^{\frac{12}{2}}$, COMPLETE $(=1$ if the deal is completed, 0 otherwise), and CROSS (=1 if the acquirer is a non-US firm, 0 otherwise); and (2) firm characteristics such as TGROWTH (the target firm growth rate), TPROFIT (the target firm's return on assets), and TLEVER (the target firms' long-term debt to equity ratio). Descriptive statistics for these control variables are shown in Panel C of Table 2.

The regressions presented in column (1) of Table 3 are consistent with the Panel A, Table 2 finding that the identity of the financial advisor does not have any significant impact on target abnormal returns. That is, the coefficients on the DUMBANK $(=1$ if there is at least one commercial bank advisor and 0 otherwise) and MIDTIER variables (=1 if all advisors are mid tier investment banks and 0 otherwise) are insignificantly different from zero. However, controlling for deal and firm characteristics, the positive and significant (at the 5\% level) coefficient on the

\footnotetext{
${ }^{31}$ However, the mean difference is not statistically significant.

${ }^{32}$ We tested the cross product of the ATTITUDE variable with the relationship dummy variables and found no
} 
DUMBANK variable in column (2) of Table 3 shows that target abnormal returns are highest for mergers advised by commercial banks. This result suggests that commercial bank financial advisors play some role in enhancing target firm abnormal returns. Moreover, consistent with the literature, we find that cash financing has a strong positive impact (significant at the 1\%) level on target abnormal returns.

Panel A of Table 2 shows that without controlling for prior banking relationships or deal characteristics, the average acquirer 3-day abnormal return is significantly lower for deals advised by top tier investment banks. The uncontrolled regression shown in column (3) of Table 3 is consistent with that finding. That is, the coefficients on the DUMBANK and MIDTIER variables are significantly positive (at the $10 \%$ level or better) indicating that acquirer returns are higher for deals advised by either commercial bank or mid tier investment bank advisors than for the omitted top tier investment bank advisor group. However, this result is not obtained when we control for deal characteristics. That is, the coefficients on the DUMBANK variable and MIDTIER are insignificant in the regressions presented in column (4) in Table 3.

The results for the control variables presented in column (4) in Table 3 are consistent with previous studies. Acquirer returns are positively related to PCTCASH (significant at the $1 \%$ level), and BVPREM (significant at the 5\% level) and negatively related to TGROWTH and TPROFIT (both significant at the 5\% level). Interestingly, acquirer returns are significantly higher (at the 5\% level or better) for deals announced in 1995, 1996, 1998, and 1999 as compared to the omitted base year of 2000.

In summary, the results in Table 3 suggest that commercial bank advisors enhance the abnormal returns earned by target firms upon merger announcement, but not those of acquirers.

significance. 
However, the results in Table 3 do not control for prior banking relationships between advisors and merger counterparties. In Section 5.2.1, we examine average abnormal returns for both the target and acquirer controlling for prior lending relationships. In Section 5.2.2, we report results of multivariate regressions of lending relationships and control variables on target abnormal returns. In Section 5.2.3, we perform the same multivariate regression analysis, but instead with acquirer abnormal returns as the dependent variable. We summarize our findings on the relationship between lending relationships and acquirer and target abnormal returns in Section 5.2.4.

\subsubsection{Mean Target and Acquirer Abnormal Returns Controlling for Banking}

\section{Relationships}

Panel A in Table 2 presents average 3-day abnormal returns for both targets and acquirers without controlling for the existence of prior banking relationships between the advisors and the merger counterparties. In Table 2, Panel B, we show how lending relationships impact average 3-day abnormal returns for targets and acquirers. The mean target abnormal return for deals in which the target advisor has had a prior banking relationship with the target $\left(T B \_B T=1\right)$ is $4.25 \%$, significant at the $1 \%$ level. This is significantly higher (at the $10 \%$ level) than the mean target abnormal return for no prior relationship (i.e., $T B \_B T=0$ ) mergers of $3.12 \%$, suggesting that target firms earn higher abnormal returns if they hire their own commercial bank as advisor. Acquirer returns tend to be significantly negative for all relationships. However, acquirer returns are lowest (mean difference significant at the $10 \%$ level or above) when both the target and acquirer advisors have prior banking relationships. Moreover, the use of the acquirer's bank as the target's advisor is the most damaging to the acquirer's abnormal returns, with a mean of 
$-0.69 \%$ which is significantly lower (at the $5 \%$ level) than the mean of $-0.22 \%$ for deals in which the target advisor has not had a prior relationship with the acquirer. This result suggests that the target firm's access to information about the acquirer is potentially damaging to the acquirer in merger negotiations.

Acquirer returns are highest (insignificantly different from zero, rather than significantly negative) when the acquirer's bank is chosen as an advisor that subsequently lends to the acquirer either one year after the merger announcement (for a mean of $-0.49 \%$, insignificantly different from zero) or up to two years after the merger announcement (statistically insignificant mean of $0.46 \%$ ). Thus, the contribution of financial advisors to acquiring firms does not appear to emanate from increased abnormal returns obtained in the context of the zero sum merger price negotiation. Rather, these results suggest that acquirers gain when their bank is chosen as an advisor because this enhances the likelihood that the advisor will subsequently finance the transition period during which the merger is consolidated. ${ }^{3}$

\subsubsection{Target Abnormal Returns Controlling for Banking Relationships}

Table 4 shows that target abnormal returns are affected by prior banking relationships. The narrow regression results presented in Table 4, column (1) show that targets benefit from hiring their own banks as advisors in mergers and acquisitions, as denoted by the dummy variable $T B \_B T$. Regressing the four relationship dummies $\left(T B \_B T, T B \_B A, A B \_B T\right.$, and $A B \_B A$ ) on target abnormal returns yields a positive coefficient for $T B \_B T$ (significant at the $5 \%$ level). All other relationship dummy variables are statistically insignificant. Thus, the nature of the prior relationship between the bank advisor and its merger counterparty is important in

\footnotetext{
${ }^{33}$ This result may also be consistent with a "double certification" effect, in which the bank certifies the value of the deal by both advising the merger and committing to future lending. However, despite this certification, acquirer
} 
determining the size of a target's abnormal returns. Further, the addition of control variables does not eliminate the impact of bank relationships on a target's abnormal returns, but rather enhances its significance. In both columns (2) and (3) of Table 4, the $T B \_B T$ coefficient remains statistically positive and significant at the $1 \%$ level when other control variables are added.

Results for the control variables shown in columns (2) and (3) of Table 4 are consistent with the literature that show that cash financed mergers have significantly (at the $1 \%$ level) higher target abnormal returns, as denoted by the positive coefficients on PCTCASH. None of the other control variables are statistically significant.

\subsubsection{Acquirer Abnormal Returns Controlling for Banking Relationships}

Table 5 analyzes acquirer abnormal returns controlling for banking relationships. In the narrow regression results shown in column (1) of Table 5 none of the relationship variables is significant, but the negative coefficient on the TOPTIER variable ( $=1$ if at least one advisor is a top tier investment bank and there are no commercial banks, 0 otherwise) is significant at the $10 \%$ level. This is consistent with the means presented in Panel A of Table 2 showing that average abnormal returns are lowest for the acquirer when the advisors are top tier investment banks. However, although this result holds in column (2) of Table 5 (when control variables are added), it is not statistically significant in column (3) of Table 5 when the full set of control variables (including year dummy variables) are entered as explanatory variables.

Table 5 presents some evidence that the gains to targets from hiring their own bank may come at the expense of acquirers. The negative coefficient on $T B \_B T$ (significant at the $10 \%$ level or better) in columns (2) and (3) of Table 5 shows that the target's gain in merger negotiations is the acquirer's loss. That is, if targets use their banks to certify a higher firm 
value, then the costs of the acquisition, and therefore the abnormal returns to the acquirer are decreased.

Introduction of the control variables into columns (2) and (3) of Table 5 indicates that the coefficient on PCTCASH is significantly positive (at the $1 \%$ level). All other control variables show similar coefficients to the model presented in column (4) of Table 3 with the exception of the merger year effect. Acquirer abnormal returns are highest for mergers announced in 1995 and 1996 as compared to the base case year 2000, as evident from the significantly positive (at the $5 \%$ level) coefficients on the $D 95$ and $D 96$ variables.

\subsubsection{Summary of Tests Assessing the Contribution of Prior Banking Relationships to Target and Acquirer Abnormal Returns}

There are two major results that are consistent throughout Tables 2, 3, 4, and 5, as well as in other robustness tests not discussed above. ${ }^{36}$ The first is that target firms earn significantly higher abnormal returns upon a merger announcement when they hire their own banks as their merger advisor. We interpret this result as evidence of a bank certification role in merger advisement for the more informationally opaque target firms. That is, the target can negotiate a better price if its own bank certifies its value.

The second major finding is that using commercial banks as advisors appears to play no

\footnotetext{
${ }^{34}$ One possible reason that acquirers may not benefit from prior banking relationships may be that the target advisor uses its information asymmetrically to benefit its own client (which is the target), thereby certifying that an acquirer's bid price is too low, but not that it is too high.

35 The ACCESS control variable (which takes on a value of 1 ( 0 otherwise) if the acquirer's bank lends to the acquirer up to one year after the merger announcement) is insignificant in all models presented in Table 5, because the market may not know of these future loans upon merger announcement.

${ }^{36}$ We performed robustness tests using all of the control variables presented in Table 1. Moreover, we tested whether the bank advisor's certification effect was more important for deals that are relatively complex such as those involving tender offers or stock swaps. When we tested this hypothesis by segmenting the sample of commercial bank-advised mergers into subsamples of commercial bank-advised deals both with and without tender offers, as well as subsamples both with and without stock swaps, we found support for our basic result that targets increase their abnormal returns by hiring their own banks as advisors.
} 
role in impacting acquirer abnormal returns. That is, we find no evidence of a certification effect for bank advisors that have had prior lending relationships with the acquirer. However, although acquirer abnormal returns are not significantly affected by the existence of a prior banking relationship, the acquiring firm is not indifferent to the choice of financial advisor as is discussed in the next section. In Section 5.3, we examine the factors that impact the acquirer's choice of merger advisor.

\subsection{The Choice of Financial Advisor}

Up until this point, we have made the implicit assumption that the choice of an advisor is exogenous. However, the identity of the merger advisor may be endogenously determined by the intensity of prior banking relationships. For example, the existence of a prior lending relationship proved critical in the choice of financial advisor in the (since abandoned) Enron Corporation - Dynegy merger announced in November 2001. According to the Wall Street Journal, November 28, 2001, page C1: 17

JP Morgan Chase \& Co. and Citigroup Inc. have emerged as prominent financiers and cheerleaders behind the problem-plagued [Enron-Dynegy merger] transaction, putting hundreds of millions of their own money into Enron in hopes of keeping the deal alive. ...Each bank has commitments outstanding to Enron, in the form of various loans, of roughly $\$ 700$ million to $\$ 800$ million, according to officials familiar with the matter, and roughly half of that is in unsecured debt....Goldman Sachs Group, an investment bank that doesn't traditionally extend large loans to clients, was denied a piece of the merger business because it declined to extend the sort of loans that JP Morgan and Citigroup provided last week.

Access to credit appears to be an important motive influencing the choice of merger

\footnotetext{
${ }^{37}$ We use the Enron-Dynegy merger (although it is not part of our sample) as an illustration, although it is far from the only case. For example, JP Morgan Chase and Citigroup offered a generous financing package in order to attract the merger advisement business of Lucent away from their long-standing investment bankers. This is an indication of a bank conflict of interest documented in Section 5.4.
} 
advisor for an acquirer. Thus, acquirers may prefer to hire commercial bank advisors, particularly those with lending relationships (to either of the merger counterparties), because they are in a position to make loans to the merged entity. To examine this further, we test the link between choice of merger advisor and lending relationships using a binomial logit model shown in Table 6. The dependent variable $S$ takes on a value of 0 if the merger advisors to both the target and the acquirer are either investment banks or commercial banks with no prior lending relationships to either merger party and 1 if either the target or the acquirer financial advisor is a commercial bank with a prior lending relationship to either of the merger counterparties. ${ }^{3.8}$

The independent variables in the logit model in Table 6 depict the intensity of the prior banking relationship. We use the Loan Pricing Corporation database (LPC) to measure relationship intensity. ${ }^{9}$ There are three prior relationship intensity variables: LENDER, DURATION and PURPOSE. LENDER takes on three possible values: 2 if LPC records that the lender was an agent or arranger of the loan syndication, 1 if LPC records that the lender was only a participant in the loan syndication, and 0 if there was no lending relationship. Thus, the higher the value of $L E N D E R$, the more intense the prior banking relationship. We examine the $L E N D E R$ variable for each of the banking relationships $\left(T B \_B T, T B \_B A, A B \_B T, A B \_B A\right)$ independently, i.e., $L E N D E R \_T B B A$ denotes the intensity of the lending relationship between the target advisor and the acquiring firm.

The second independent variable, DURATION, denotes the time period between the

\footnotetext{
${ }^{38}$ We also tested a disaggregated model (not shown) that examined the target's choice independently of the acquirer's choice of financial advisor. We found that there was no significant impact of the prior lending relationship on the target's choice. This is consistent with the target's concern with maximizing its abnormal return upon merger announcement. In contrast, the acquirer would be concerned with access to capital to finance the integration of the two firms. We find that the intensity of the prior lending relationship has a significant impact on the acquirer's choice of financial advisor.

${ }^{39}$ Since we have LPC data for only a subset of the database, we estimate the model in Table 6 using 241 observations.
} 
merger announcement date and the origination date of the earliest loan syndication for both the target and the acquirer involving each bank advisor (denoted as $T B \_B T, T B \_B A, A B \_B T$, and $\left.A B \_B A\right)$. Thus, the longer DURATION, the more long-lived the prior banking relationship. Finally, PURPOSE is an LPC variable that takes on three possible values: 2 if the loan was made for general business purposes, 1 if it was merger related and 0 if there was no loan relationship. Since we are interested in the bank's access to private information about the firm's activities prior to the merger announcement, we hypothesize that the higher the PURPOSE variable, the greater the information content generated by the lending relationship. That is, merger related loan syndications tend to have somewhat narrow focus and are of limited duration. Instead, general business lending allows the bank to obtain information about the day to day investment and financing activities of the firm. Finally, we define all three variables LENDER, DURATION and PURPOSE for non-advisor banks as well as advisor banks.

The results presented in Table 6 confirm the hypothesis that the more intense the prior lending relationship, the greater the likelihood that the commercial bank is chosen as financial advisor. Moreover, it is the intensity of the prior lending relationship with the acquirer that determines the choice of financial advisor, in contrast to the role of the prior lending relationship with the target that generated the certification gains documented in Section 5.2. That is all three variables LENDER, DURATION and PURPOSE are positive and significant (at the 5\% level) for the $A B \_B A$ relationship, suggesting that the more intense the prior relationship between the acquiring firm and the acquirer's bank advisor, the greater the likelihood that a commercial bank will be chosen as merger advisor. The only other relationship variable that is statistically significant (at the $10 \%$ level or better) is the LENDER variable for all possible banking relationships $T B \_B T, T B \_B A$, and $A B \_B T$. This suggests that the more lending relationships that 
exist for both target and acquirer, the more likely they are to choose a commercial bank advisor. Finally, we examine the merger counterparties' lending relationships with banks not chosen as merger advisors and denote them Nonadvisor in Table 6. We find that most Nonadvisor variables are insignificant, with the exception of Nonadvisor Purpose_A, which denotes the relationship between the acquirer and nonadvisor commercial banks. The more that the acquirer has borrowed for general business purposes prior to the merger announcement date, the greater the likelihood that a commercial bank advisor will be chosen.

Although the LENDER, DURATION and PURPOSE variables measure the intensity of prior banking relationships, the existence of past lending does not necessarily guarantee future lending by the bank advisor. To address this issue, we constructed another dummy variable, ACCESS. This variable takes on a value of 1 ( 0 otherwise) if the acquirer's bank is chosen as a financial advisor (by either the target or the acquirer) and the bank lends to the acquirer at any time up to one year after the merger announcement date. ${ }^{40}$ Table 6 shows that the coefficient on this variable is positive and significant at the $5 \%$ level, indicating that the access to financing in the future offered by commercial banks with prior lending relationships increases the likelihood that a commercial bank is chosen to advise the merger counterparties. ${ }^{-1}$ These positive results on the ACCESS variable were robust for different specifications of the logit model. The model's chi-square likelihood ratio test for goodness of fit was 87.8818 , significant at the $1 \%$ level. Thus, we conclude that the relationship between the commercial bank advisor and the acquiring firm

\footnotetext{
${ }^{40}$ We also tested a two year $A C C E S S$ variable (=1 if there was a loan to the acquirer within two years after the merger announcement) and obtained the same results as reported in Table 6.

${ }^{41}$ The ACCESS variable is included in the acquirer abnormal return regressions presented in Table 5. The coefficient is insignificant, perhaps because the market was unaware on the merger announcement date that the financing would take place in the future.
} 
primarily impacts the acquirer's access to credit rather than the acquirer's abnormal returns.

\subsection{Bank Advisor Abnormal Returns}

In Section 5.2, we found evidence of a bank certification effect in which banks that had prior lending relationships with target firms used their private information to enhance target abnormal returns. In Section 5.3, we found that acquirers, in contrast to targets, are primarily concerned about access to credit at and after the merger announcement date. Thus, whenever possible, targets hire their own banks as merger advisors in order to maximize their abnormal returns, whereas acquirers hire their own banks as merger advisors in order to maximize the

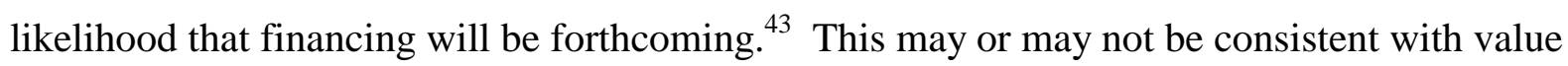
maximization goals. In this section, we examine the impact of prior banking relationships on bank advisor abnormal returns.

We estimate the market model over the period January 1, 1995 through December 31, $2000^{44}$ for the eight (publicly traded) commercial bank advisors most active in our sample: Citicorp (before Travelers), Citigroup, FleetBoston, BankBoston (before Fleet), Bankers Trust (before Deutschebank), Chase Manhattan (before JP Morgan), JP Morgan (before Chase), and Bank of America (including Nationsbank). We estimate a pooled return generating model for all

\footnotetext{
${ }^{42}$ Note that the acquirer is not necessarily constrained to follow value-maximizing policies if agency problems permit management to pursue value-reducing mergers. See discussion in Section 2.3.

${ }^{43}$ Of course, this may not be possible if the target or acquirer bank does not offer merger advisement services. Since smaller firms gravitate to smaller banks [see Berger and Udell (1995)] that are less likely to offer this service, this is more likely to be a constraint for targets than for acquirers.

${ }^{44}$ We used all bank advisors in our sample that were publicly traded on either NYSE, AMEX, or Nasdaq for any length of time during our sample period. Thus, we include banks that are no longer in existence such as JP Morgan Bank and BankBoston.
} 
eight bank advisor returns using a single market index (the CRSP equally weighted index) 45 and a dummy variable EVENT PERIOD that takes on a value of 1 for each day before, on, and after a merger announcement in which the bank serves as advisor to either counterparty (i.e., we define a 3-day event window corresponding to the $(-1,+1)$ event period). Control variables such as SIZE, RELSIZE and ACCESS were used.

Table 7 shows that the impact of prior banking relationships on bank advisor abnormal returns is evaluated using two different approaches. First, we utilize the bank relationship dummy variables, $T B \_B T, T B \_B A, A B \_B T, A B \_B A$, to estimate the bank advisors' abnormal returns upon merger announcement for deals with various prior lending relationships. All relationships are insignificant, with the exception of $A B \_B A$ that has a negative coefficient, significant at the 5\% level. However, $A B \_B A$ denotes that the acquirer's advisor is a bank with a prior relationship with the acquirer, but does not specify which bank is that advisor. Thus, we add two dummy variables DTARADV (DACQADV) which take on a value of 1 if the dependent variable bank is the target's (acquirer's) advisor. The negative coefficient in column (1) of Table 7 (significant at the 5\%) level shows that bank abnormal returns decline significantly when the bank provides merger advice to acquirers with whom they have had a prior banking relationship.

This result is robust across all model specifications. For example, in column (2) of Table 7 we explicitly define the bank's relationship to both the target and acquirer. For example, the coefficient on the $T B \_B T x D T A R A D V$ variable denotes the impact on bank abnormal returns of

\footnotetext{
${ }^{45}$ We also estimated a disaggregated return generating function that allowed the betas to vary across banks. We do not present those results since they are quite similar to those presented in Table 7 . We were unable to estimate a SUR simultaneous equations model because the estimation period varied across bank advisors.

${ }^{46}$ The abnormal return to the bank of advising its own customer in an acquisition is the sum of the coefficients on $A B \_B A$ and $D A C Q A D V$, or -0.0121 for an average decline in bank advisor abnormal returns of $1.21 \%$.
} 
advising the target in a merger if the bank has had a prior banking relationship with the target.

Thus, the negative coefficient on $A B \_B A \times D A C Q A D V$ (significant at the $1 \%$ level) indicates that bank abnormal returns significantly decline if the bank offers merger advice to an acquirer with which the bank has had a prior banking relationship. The market, overall, penalizes a bank for advising its own customer in a merger if that bank customer is an acquirer.

This result can be understood by recalling that the acquirer's incentive to hire its own commercial bank as merger advisor was access to credit (see Section 5.3). The market is concerned about a potential conflict of interest as commercial bank advisors continue lending to acquirers in return for merger advisory fees. The advisor's implicit (or explicit) promise to provide credit is viewed as a potential conflict of interest by the market and weakens any perceived profits resulting from merger advisory fees; i.e., losses on future loan commitments (as well as related adverse reputational effects) may more than offset merger advisory fees. Using the Enron-Dynegy merger as an example, from the Wall Street Journal, November 28, 2001, page $\mathrm{C} 15$ :

JP Morgan and Citigroup, who have served as the top underwriters of [Enron's] debt, would rather avoid being blamed for letting Enron's debt go bad. Even more importantly, they also hold their own portion of that debt. Thus, both banks recently provided an additional credit line to Enron totaling \$1 billion....[S]peaking privately, bankers concede that a failure of the Enron deal would smart beyond what the damage might be to the banks' loan portfolio. 'If it falls apart,' says Mr. Hayes, the Harvard professor, 'it will be a source of embarrassment.'

Of course, the Enron-Dynegy deal did subsequently fall apart in November 2001, thereby validating the market's concerns about bank conflicts of interest when banks provide merger advice to their own clients in the course of an acquisition. Indeed, on the day after the announcement of the Enron bankruptcy filing, Citigroup's stock price declined more than 2\% and 
JP Morgan Chase's stock price fell by more than 3\%.

\section{Conclusions}

This paper examines the role of commercial banks as advisors to merger participants. If the role of a financial advisor in a merger is to mobilize information, then commercial banks potentially have a comparative advantage in advising their banking customers as compared to non-bank advisors (i.e., traditional investment banks). We refer to this as the bank certification effect. All else being equal, we would expect that access to information generated in the course of a lending/credit relationship would enhance the merger counterparty's abnormal return upon announcement of a merger. However, there is a countervailing influence to the certification effect in that the commercial bank may be faced with a conflict of interest that diminishes the value of any such certification effect. In particular, the bank may be unable to credibly relay information to the market and investors at large if there is concern that the bank's merger advice is clouded by other objectives, such as the repayment of outstanding loans and potential profits from future lending activity. Alternatively, the bank's lending decisions may be distorted by the bank's desire to capture merger advisory fees. Whichever effect predominates determines whether using commercial bank advisors increases or decreases acquirer's and/or target's abnormal returns in mergers and acquisitions.

We examine empirically this issue using a sample of 488 merger deals announced during the time period from January 1, 1995 through December 31, 2000. Of these sampled mergers, 299 utilize one or more commercial bank advisors who advise either the target, or the acquirer, or both. The other 189 sampled merger deals constitute our investment bank control group in which there are no commercial bank advisors, and both the target and the acquirer hire either top tier or mid tier investment bank advisors. 
We find evidence of a bank certification effect for target firms only. This certification effect takes the form of increased abnormal returns to targets whenever their merger advisor is their own bank (with whom the target has had a prior banking relationship). In contrast, acquirer abnormal returns are either negative or insignificantly different from zero in all cases. Moreover, acquirers appear to utilize prior lending relationships to direct their choice of advisor. The more intense the prior banking relationship between the acquirer and the bank, the more likely it is that that bank will be chosen to advise the acquiring firm in a merger. This is because the acquirer extracts implicit or explicit commitments regarding access to bank loans in the future postmerger period. This creates a potential conflict of interest, which is priced by the market in the form of a significantly negative impact on bank abnormal returns upon announcement of a merger in which the acquirer's advisor is the acquirer's bank. 


\section{$\underline{\text { References }}$}

Agrawal, A., J. Jaffe, and G. Mandelker, 1992, The Post-Merger Performance of Acquiring Firms: A Re-Examination of an Anomaly, Journal of Finance 47 (September 1992) 1605-1621.

Amihud, Y., and J. Kamin, 1979, "Revenue vs. Profit Maximization: Differences in Behavior Type of Control and Market Power," Southern Economic Journal, 45, 838-46.

Amihud, Y., J. Kamin, and J. Ronen, 1983, “Managerialism, Ownerism, and Risk,” Journal of Banking and Finance, 7, 189-96.

Amihud, Y. and B. Lev, 1981, "Risk Reduction as a Managerial Motive for Conglomerate Merger,” Bell Journal of Economics, Autumn, 605-17.

Amihud, Y., B. Lev, and N. Travlos, 1990, "Corporate Control and the Choice of Investment Financing: The Case of Corporate Acquisitions," Journal of Finance 45, 603-616.

Ang, J. and T. Richardson, 1994, "The Underwriting Experience of Commercial Bank Affiliates Prior to the Glass Steagall Act: A Reexamination of Evidence for the Passage of the Act," Journal of Banking and Finance 18, 351-395.

Beatty, A., A. Santomero, and M. Smirlock, 1987, "Bank Merger Premiums: Analysis and Evidence," Monograph Series in Finance and Economics, No. 3, Salomon Brothers Center for the Study of Financial Institutions, NYU.

Benston, G., 1990, "The Separation of Commercial and Investment Banking: The Glass Steagall Act Revisited and Reconsidered," New York: Oxford University Press.

Berger, A. and D.B. Humphrey, 1992, "Megamergers in Banking and the Use of Cost Efficiency as an Antitrust Defense," The Antitrust Bulletin, 37 (3), 541-600.

Berger, A. and G. Udell, 1995, "Relationship Lending and Lines of Credit in Small Firm Finance," Journal of Business, 68, 351-381.

Berkovitch, E. and M.P. Narayanan, 1993, Motives for Takeovers: An Empirical Investigation, Journal of Financial and Quantitative Analysis 28 (September) 347-361.

Bowers, H.M. and R. Miller, 1990, Choice of Investment Banker and Shareholders Wealth of Firms Involved in Acquisitions, Financial Management 19, 34-44.

Bradley, M., A. Desai, and E.H. Kim, 1988, Synergistic Gains from Corporate Acquisitions and their Division Between the Stockholders of Target and Acquiring Firms, Journal of Financial Economics 21, 3-40.

Brown, D. and M. Ryngaert, 1991, The Mode of Acquisition in Takeovers: Taxes and 
Asymmetric Information, Journal of Finance 46 (June) 653-669.

Chan, Y.S., Greenbaum, S., A. Thakor, 1986, "Information Reusability, Competition, and Bank Asset Quality,” Journal of Banking and Finance, 10, 2, 243-53.

Comment, R. and G.W. Schwert, 1995, "Poison or Placebo? Evidence on the Deterrence and Wealth Effects of Modern Antitakeover Measures," Journal of Financial Economics, 39, 3-43.

Cotter, J. and M. Zenner, 1994, How Managerial Wealth Affects the Tender Offer Process, Journal of Financial Economics 35 (February) 63-97.

Cybo-Ottone, A. and M. Murgia, 2000, "Mergers and Shareholder Wealth in European Banking," Journal of Banking and Finance, 24, 831-859.

Diamond, D., 1991, "Monitoring and Reputation: The Choice Between Bank Loans and Directly Placed Debt," Journal of Political Economy 99, 689-721.

Doukas, J. and N. Travlos, 1988, “The Effect of Corporate Multinationalism on Shareholders' Wealth: Evidence from International Acquisitions, Journal of Finance, 43 (5), 1161-75.

Fama, E., 1985, “What's Different About Banks?” Journal of Monetary Economics, 15, 29-39.

Fama, E., L. Fisher, M. Jensen, and R. Roll, 1969, The Adjustment of Stock Prices to New Information, International Economic Review 10, 1-21.

Franks, J. and C. Mayer, 1996, Hostile Takeovers and the Correction of Managerial Failure, Journal of Financial Economics 40 (January) 163-181.

Gande, A., M. Puri, A. Saunders, and I. Walter, 1997, Bank Underwriting of Debt Securities: Modern Evidence, Review of Financial Studies, 10, 4, 1175-1202.

Garner, J.L, and J.R. Kale, 2001, "The Effect of Past Mispricing on the Composition of Future IPO Syndicates," Georgia State University Working Paper, July.

Harris, M. and A. Raviv, 1988, "Corporate Control Contests and Capital Structure." Journal of Financial Economics 20, 55-86.

Healy, P.M, K.G. Palepu, and R.S. Ruback, 1992, “Does Corporate Performance Improve After Mergers?” Journal of Financial Economics, 31, 135-75.

Hebb, G., 1999, “Commercial Bank Involvement in Equity Underwritings,” Working Paper, August.

Hubbard, R.G. and D. Palia, 1999, "A Re-Examination of the Conglomerate Merger Wave in the 1960s: An Internal Capital Markets View,” Journal of Finance, 54, 3 (June) 1131-52. 
Hunter, W.C. and J. Jagtiani, 2001, "Merger Advisory Fees and Advisors' Effort,” Working Paper Federal Reserve Bank of Chicago Emerging Issues Series No. S\&R 2001-11R.

Hunter, W.C. and M.B. Walker, 1990, An Empirical Examination of Investment Banking Merger Fee Contracts, Southern Economic Journal, 56, 1117-1130.

James, C. 1992, "Relation-specific Assets and the Pricing of Underwriter Services," Journal of Finance, 47 (5), 1865-85.

James, C. and P. Weir, 1987, "Returns to Acquirers and Competition in the Acquisition Market: The Case of Banking," Journal of Political Economy, 95, 355-70.

Jensen, M. and R. Ruback, 1983, The Market for Corporate Control: The Scientific Evidence, Journal of Financial Economics, 11, 5-50.

Kang, J.K., 1993, The International Market for Corporate Control, Journal of Financial Economics 34 (December) 345-371.

Kroszner, R. and R. Rajan, 1994, Is Glass-Steagall Act Justifies? A Study of the U.S. Experience with Universal Banking Before 1933, American Economic Review 84, 4, 810-831.

Lloyd, W., J. Hand, and N. Modani, 1987, "The Effect of the Degree of Ownership Control on Firm Diversification, Market Value, and Merger Activity," Journal of Business Research, 15, 303-12.

Linn, S.C. and J.A. Switzer, 2001, “Are Cash Acquisitions Associated with Better Postcombination Operating Performance than Stock Acquisitions?" Journal of Banking and Finance, 25, 1113-1138.

McLaughlin, R.M., 1992, Does the Form of Compensation Matter? Investment Banker Fee Contracts in Tender Offers, Journal of Financial Economics 32, 223-260.

McLaughlin, R.M., 1990, Investment-Banking Contracts in Tender Offers: An Empirical Analysis, Journal of Financial Economics 28 (November/December) 209-232.

Michaely, R. and K.L. Womack, 1999, "Conflict of Interest and the Credibility of Underwriter Analyst Recommendations," The Review of Financial Studies, 12 (4), 653-686.

Palia, D., 1994, "Recent Evidence of Bank Mergers," Financial Markets, Instruments, and Institutions, 3, no. 5, 36-59.

Puri, M., 1994, The Long-Term Default Performance of Bank Underwritten Security Issues, Journal of Banking and Finance 18, 397-418.

Puri, M., 1996, Commercial Banks in Investment Banking: Conflict of Interest or Certification 
Role? Journal of Financial Economics 40, 373-401.

Rajan, R., 1992, "Insiders and Outsiders: The Choice Between Informed and Arm's-Length Debt, Journal of Finance, 47, 1367-1400.

Rau, R., 2000, "Investment Bank Market Share, Contingent Fee Payments, and the Performance of Acquiring Firms," Journal of Financial Economics, vol. 56, 293-324.

Rajan, R., H. Servaes, and L. Zingales, 2000, "The Cost of Diversity: The Diversification Discount and Inefficient Investment," Journal of Finance, 55, 1 (February) 35-80.

Roll, R., 1986, "The Hubris Hypothesis of Corporate Takeovers," Journal of Business 59 no. 2, 197-216.

Sapsford, J. and K. Scannell, 2001, "Banks, Too, Have Stake in Enron Merger," Wall Street Journal, November 28, 2001, C1, C15.

Servaes, H., 1996, "The Value of Diversification During the Conglomerate Merger Wave," Journal of Finance, 51, 4 (September), 1201-25.

Servaes, H. and M. Zenner, 1996, The Role of Investment Banks in Acquisition, The Review of Financial Studies 9 (Fall) 787-815.

Smith, R., 2001, "Lehman Faced Possible Conflict as Merger Failed," Wall Street Journal, December 5, 2001, p. C1, C11.

Saunders, A. and Srinivasan, A., 2001, "Investment Banking Relationships and Merger Fees," NYU Working Paper, October.

Stulz, R., 1988, "Managerial Control of Voting Rights: Financial Policies and the Market for Corporate Control." Journal of Financial Economics, 20, 25-54.

Stulz, R., R. Walkling, and M. Song, 1990, The Distribution of Target Ownership and the Division of Gains in Successful Takeovers, Journal of Finance 45 (July) 817-833.

Travlos, N., 1987, Corporate Takeover Bids, Means of Payment, and Bidding Firms Stock Returns, Journal of Finance, 42, 943-964. 


\section{Table 1. Definition of Variables}

\begin{tabular}{|c|c|}
\hline TB_BT & $\begin{array}{l}\text { Dummy variable }=1 \text { if the target's advisor is a bank which has a prior banking relationship with the } \\
\text { target; } 0 \text { otherwise. }\end{array}$ \\
\hline TB_BA & $\begin{array}{l}\text { Dummy variable }=1 \text { if the target's advisor is a bank which has a prior banking relationship with the } \\
\text { acquirer; } 0 \text { otherwise. }\end{array}$ \\
\hline AB_BT & $\begin{array}{l}\text { Dummy variable }=1 \text { if the acquirer's advisor is a bank which has a prior banking relationship with } \\
\text { the target; } 0 \text { otherwise. }\end{array}$ \\
\hline AB_BA & $\begin{array}{l}\text { Dummy variable }=1 \text { if the acquirer's advisor is a bank which has a prior banking relationship with } \\
\text { the acquirer; } 0 \text { otherwise. }\end{array}$ \\
\hline TOPTIER & $\begin{array}{l}\text { Dummy variable }=1 \text { if at least one advisor is a commercial bank; }=0 \text { if there is at least one top tier } \\
\text { investment bank (i.e., Goldman Sachs, CSFB, Salomon, or MSDW) advising target/acquirer, and no } \\
\text { commercial bank advisors. }\end{array}$ \\
\hline MIDTIER & $\begin{array}{l}\text { Dummy variable }=1 \text { if all advisors are mid tier investment banks (i.e., Bear Stearns, Lehman } \\
\text { Brothers, Lazard Freres, Paine Webber, etc.), and no commercial bank advisors. }\end{array}$ \\
\hline PCTCASH & Percentage of cash used to finance the deal (percent). \\
\hline BVPREM & Offering premium over target's book value (market price/book value in percent). \\
\hline ATTITUDE & Dummy variable $=1$ if the deal is friendly; 0 if it is neutral; -1 if it is hostile (as designated by SDC). \\
\hline CROSS & Dummy variable $=1$ if the merger crossed borders; 0 if not. \\
\hline TGROWTH & $\begin{array}{l}\text { Target firm growth rate (as measured by the } 1-3 \text { year annualized percent growth rate in either cash } \\
\text { flows or earnings per share, whenever available) }\end{array}$ \\
\hline TPROFIT & Target firm return on assets (pretax income/total assets in percent). \\
\hline TLEVER & Target firm leverage (ratio of target long-term debt shareholders equity in percent). \\
\hline COMPLETE & Dummy variable $=1$ if completed deal; 0 otherwise. \\
\hline RELSIZE & $\begin{array}{l}\text { Relative firm size (target firm market cap/acquirer market cap as of merger announcement date in } \\
\text { percent). }\end{array}$ \\
\hline ACCESS & $\begin{array}{l}\text { Dummy variable }=1 \text { if the acquirer's bank is hired as an advisor and lends to the acquirer up to } 1 \text { year } \\
\text { after the announcement date; } 0 \text { otherwise. }\end{array}$ \\
\hline \multicolumn{2}{|c|}{ ROBUSTNESS VARIABLES } \\
\hline MERGER & Dummy variable $=1$ if the merger is for complete target acquisitions; $=0$ if partial acquisition. \\
\hline PROTECT & $\begin{array}{l}\text { Dummy variable }=1 \text { if there are protective mechanisms such as poison pills, defensive } \\
\text { recapitalization, scorched earth defenses, etc. }\end{array}$ \\
\hline $\begin{array}{l}\text { SFC, SFCORP, } \\
\text { SFDEBT, SWAP }\end{array}$ & $\begin{array}{l}\text { Dummy variable=1 if financing includes corporate stock (SFC), internal funds (SFCORP), debt } \\
\text { (SFDEBT), SWAP (stock swap). }\end{array}$ \\
\hline CASHFLOW & Target Firm value minus cash assets divided by total assets (percent). \\
\hline FEES & Total fees paid to target and acquirer advisors. \\
\hline CLOSE & Dummy variable $=1$ if the target was closely held; 0 if not. \\
\hline TOBINQ & $\begin{array}{l}\text { The target firm's market price divided by book value four weeks prior to merger announcement date } \\
\text { (percent). }\end{array}$ \\
\hline MGMT & Dummy variable $=1$ if the target's management was involved in the merger \\
\hline BLOCK & Dummy variable $=1$ if the target has block holdings of stock; 0 otherwise \\
\hline TENDER & Dummy variable $=1$ if there was a tender offer; 0 otherwise \\
\hline MOE & Dummy variable $=1$ if the merger was a merger of equals; 0 otherwise \\
\hline
\end{tabular}


Table 2. Panel A: Overall Descriptive Statistics

\begin{tabular}{|c|c|c|c|c|}
\hline \multirow[t]{3}{*}{ "Control Variables } & \multicolumn{2}{|c|}{$\overline{(-1,+1)}$ Target $S C A R$} & \multicolumn{2}{|c|}{$(-1,+1)$ Acquirer $S C A R$} \\
\hline & \multicolumn{2}{|c|}{ Control Variable } & \multicolumn{2}{|c|}{ Control Variable } \\
\hline & $\mathrm{NO}=0$ & YES=1 & $\mathrm{NO}=\mathbf{0}$ & YES=1 \\
\hline All Observations & & $\begin{array}{l}488 \text { deals } \\
3.38 \% * * *\end{array}$ & & $\begin{array}{l}495 \text { deals } \\
-0.31 \% * * *\end{array}$ \\
\hline Target advisor is a bank. & $\begin{array}{l}294 \text { deals } \\
3.31 \% * * *\end{array}$ & $\begin{array}{l}153 \text { deals } \\
3.67 \% * * *\end{array}$ & $\begin{array}{l}269 \text { deals } \\
-0.46 \% * * *\end{array}$ & $\begin{array}{l}170 \text { deals } \\
-0.14 \%\end{array}$ \\
\hline Acquirer advisor is a bank. & $\begin{array}{l}252 \text { deals } \\
3.57 \% * * *\end{array}$ & $\begin{array}{l}168 \text { deals } \\
3.30 \% * * *\end{array}$ & $\begin{array}{c}243 \text { deals } \\
-0.42 \% * * * 1 \mathrm{~A}\end{array}$ & $\begin{array}{c}172 \text { deals } \\
-0.39 \% * * * 1 \mathrm{~B}\end{array}$ \\
\hline $\begin{array}{l}\text { The target firm does not use a } \\
\text { financial advisor. }\end{array}$ & & $\begin{array}{l}41 \text { deals } \\
2.80 \% * * *\end{array}$ & & $\begin{array}{l}56 \text { deals } \\
-0.13 \%\end{array}$ \\
\hline $\begin{array}{l}\text { The acquirer does not use a } \\
\text { financial advisor. }\end{array}$ & & $\begin{array}{l}68 \text { deals } \\
2.89 \% * * *\end{array}$ & & $\begin{array}{c}80 \text { deals } \\
0.21 \%^{1 \mathrm{~A}, 1 \mathrm{~B}}\end{array}$ \\
\hline $\begin{array}{l}\text { Both advisors are top tier } \\
\text { investment banks. }\end{array}$ & $\begin{array}{l}330 \text { deals } \\
3.49 \% * * *\end{array}$ & $\begin{array}{l}158 \text { deals } \\
3.15 \% * * *\end{array}$ & $\begin{array}{l}352 \text { deals } \\
-0.19 \% * 1 \mathrm{C} \\
\end{array}$ & $\begin{array}{c}143 \text { deals } \\
-0.60 \% * * * 1 \mathrm{C}\end{array}$ \\
\hline $\begin{array}{l}\text { Both advisors are mid tier } \\
\text { investment banks. }\end{array}$ & $\begin{array}{l}457 \text { deals } \\
3.43 \% * * *\end{array}$ & $\begin{array}{c}31 \text { deals } \\
2.63 \% * * *\end{array}$ & $\begin{array}{c}463 \text { deals } \\
-0.35 \% * * * 2 \mathrm{D} \\
\end{array}$ & $\begin{array}{l}32 \text { deals } \\
0.28 \%^{2 \mathrm{D}}\end{array}$ \\
\hline $\begin{array}{l}\text { Deal attitude: }=0 \text { if friendly or } \\
\text { neutral; }=1 \text { if hostile. }\end{array}$ & $\begin{array}{c}456 \text { deals } \\
3.32 \% * * * 2 \mathrm{E}\end{array}$ & $\begin{array}{c}20 \text { deals } \\
5.12 \% * * *^{2 \mathrm{E}}\end{array}$ & $\begin{array}{c}466 \text { deals } \\
-0.31 \% * * * \\
\end{array}$ & $\begin{array}{l}18 \text { deals } \\
-0.42 \%\end{array}$ \\
\hline Year $=1995$ & & $\begin{array}{c}23 \text { deals } \\
2.83 \% * * *\end{array}$ & & $\begin{array}{l}29 \text { deals } \\
0.77 \% * *\end{array}$ \\
\hline Year $=1996$ & & $\begin{array}{c}28 \text { deals } \\
4.66 \% * * *\end{array}$ & & $\begin{array}{l}27 \text { deals } \\
0.51 \%\end{array}$ \\
\hline Year $=1997$ & & $\begin{array}{l}73 \text { deals } \\
2.59 \% * * *\end{array}$ & & $\begin{array}{l}71 \text { deals } \\
-0.39 \% *\end{array}$ \\
\hline Year $=1998$ & & $\begin{array}{l}115 \text { deals } \\
3.57 \% * * *\end{array}$ & & $\begin{array}{l}121 \text { deals } \\
-0.26 \%\end{array}$ \\
\hline Year $=1999$ & & $\begin{array}{l}61 \text { deals } \\
2.37 \% * * *\end{array}$ & & $\begin{array}{l}86 \text { deals } \\
0.19 \%\end{array}$ \\
\hline Year $=2000$ & & $\begin{array}{l}188 \text { deals } \\
3.78 \% * * *\end{array}$ & & $\begin{array}{c}161 \text { deals } \\
-0.92 \% * * *\end{array}$ \\
\hline
\end{tabular}

(Table 2 continued)

Notes: Means were not estimated for the empty cells. Standard errors in parentheses. *,**, *** denotes significance at the $10 \%, 5 \%, 1 \%$ level, respectively, testing whether the mean equals zero.

Whenever statistically significant, mean differences are reported. The significance levels of each pair of means (denoted by the same letter in the superscript of the standard error) are:

${ }^{1}$ Mean differences are significant at the $5 \%$ level.

${ }^{2}$ Mean differences are significant at the $10 \%$ level. 
Table 2 Panel B: Descriptive Statistics Controlled for Banking Relationships

\begin{tabular}{|c|c|c|c|c|}
\hline \multirow[t]{3}{*}{ Control Variables } & \multicolumn{2}{|c|}{$(-1,+1)$ Target SCAR } & \multicolumn{2}{|c|}{$(-1,+1)$ Acquirer SCAR } \\
\hline & \multicolumn{2}{|c|}{ Control Variable } & \multicolumn{2}{|c|}{ Control Variable } \\
\hline & $\mathrm{NO}=0$ & YES $=1$ & $\mathrm{NO}=0$ & YES $=1$ \\
\hline $\begin{array}{l}\text { Target advisor is a bank with a prior } \\
\text { relationship with the target (TB_BT) }\end{array}$ & $\begin{array}{c}374 \text { deals } \\
3.12 \% * * * 2 \mathrm{~F}\end{array}$ & $\begin{array}{c}110 \text { deals } \\
4.25 \% * * * 2 \mathrm{~F}\end{array}$ & $\begin{array}{c}392 \text { deals } \\
-0.24 \% * * *\end{array}$ & $\begin{array}{l}98 \text { deals } \\
-0.58 \% * *\end{array}$ \\
\hline $\begin{array}{l}\text { Target advisor is a bank with a prior } \\
\text { relationship with the acquirer (TB BA) }\end{array}$ & $\begin{array}{l}391 \text { deals } \\
3.22 \% * * *\end{array}$ & $\begin{array}{l}70 \text { deals } \\
3.41 \% * * *\end{array}$ & $\begin{array}{c}397 \text { deals } \\
-0.22 \% * * 1 \mathrm{G}\end{array}$ & $\begin{array}{c}85 \text { deals } \\
-0.69 \% * * * 1 \mathrm{G}\end{array}$ \\
\hline $\begin{array}{l}\text { Acquirer advisor is a bank with a prior } \\
\text { relationship with target (AB_BT) }\end{array}$ & $\begin{array}{l}419 \text { deals } \\
3.36 \% * * *\end{array}$ & $\begin{array}{c}63 \text { deals } \\
3.20 \% * * *\end{array}$ & $\begin{array}{r}438 \text { deals } \\
-0.28 \% * * *\end{array}$ & $\begin{array}{c}51 \text { deals } \\
-0.61 \% * *\end{array}$ \\
\hline $\begin{array}{l}\text { Acquirer advisor is a bank with a prior } \\
\text { relationship with acquirer (AB_BA) }\end{array}$ & $\begin{array}{l}386 \text { deals } \\
3.18 \% * * * *\end{array}$ & $\begin{array}{l}73 \text { deals } \\
3.34 \% * * *\end{array}$ & $\begin{array}{c}397 \text { deals } \\
-0.29 \% * * *\end{array}$ & $\begin{array}{l}84 \text { deals } \\
-0.36 \% *\end{array}$ \\
\hline $\begin{array}{l}\text { Acquirer's bank lends to acquiring firm up to } 1 \\
\text { year after deal announcement. }\end{array}$ & $\begin{array}{l}456 \text { deals } \\
3.44 \% * * * \\
\end{array}$ & $\begin{array}{r}32 \text { deals } \\
2.62 \% * * * \\
\end{array}$ & $\begin{array}{r}461 \text { deals } \\
-0.30 \% * * * \\
\end{array}$ & $\begin{array}{l}34 \text { deals } \\
-0.49 \%\end{array}$ \\
\hline $\begin{array}{l}\text { Acquirer's bank lends to acquiring firm up to } 2 \\
\text { yrs after deal announcement. }\end{array}$ & $\begin{array}{l}452 \text { deals } \\
3.44 \% * * * *\end{array}$ & $\begin{array}{c}36 \text { deals } \\
2.59 \% * * *\end{array}$ & $\begin{array}{l}454 \text { deals } \\
-0.30 \% * * *\end{array}$ & $\begin{array}{l}41 \text { deals } \\
-0.46 \%\end{array}$ \\
\hline $\begin{array}{l}\text { Both acquirer and target advisors are either non- } \\
\text { banks or banks without any prior relationships. }\end{array}$ & & $\begin{array}{l}245 \text { deals } \\
3.50 \% * * * *\end{array}$ & & $\begin{array}{c}232 \text { deals } \\
-0.45 \% * * * 2 \mathrm{H}\end{array}$ \\
\hline $\begin{array}{l}\text { Acquirer advisor is a non-bank or bank without } \\
\text { any prior relationship; target advisor has } \\
\text { relationship with either target or acquirer. }\end{array}$ & & $\begin{array}{c}42 \text { deals } \\
3.79 \% * * *\end{array}$ & & $\begin{array}{l}30 \text { deals } \\
-0.36 \%\end{array}$ \\
\hline $\begin{array}{l}\text { Target advisor is a non-bank or bank without } \\
\text { any prior relationship; acquirer advisor has } \\
\text { relationship with either target or acquirer. }\end{array}$ & & $\begin{array}{l}60 \text { deals } \\
2.69 \% * * *\end{array}$ & & $\begin{array}{l}66 \text { deals } \\
-0.33 \%^{1 \mathrm{~K}}\end{array}$ \\
\hline $\begin{array}{l}\text { Both target and acquirer advisors have prior } \\
\text { banking relationships. }\end{array}$ & & $\begin{array}{c}7 \text { deals } \\
2.83 \% * *\end{array}$ & & $\begin{array}{c}9 \text { deals } \\
-1.16 \%^{1 \mathrm{~K}, 2 \mathrm{H}, 2 \mathrm{~J}}\end{array}$ \\
\hline
\end{tabular}

(Table 2 continued)

Notes: Means were not estimated for the empty cells. Standard errors in parentheses. *,**,*** denotes significance at the $10 \%, 5 \%, 1 \%$ level, respectively, testing whether the mean equals zero.

Whenever statistically significant, mean differences are reported. The significance levels of each pair of means (denoted by the same letter in the superscript of the standard error) are:

${ }^{1}$ Mean differences are significant at the 5\% level.

${ }^{2}$ Mean differences are significant at the $10 \%$ level. 
Table 2 Panel C: Descriptive Statistics for Control Variables

\begin{tabular}{|c|c|c|c|c|c|}
\hline $\begin{array}{l}\text { Control } \\
\text { Variables }\end{array}$ & Variable Description & $\mathbf{N}$ & $\begin{array}{l}\text { Mean } \\
\text { (Std) }\end{array}$ & Minimum & Maximum \\
\hline BVPREM & $\begin{array}{l}\text { Premium of offer price } \\
\text { over target book value. }\end{array}$ & 448 & $\begin{array}{c}4.74 * * * \\
(6.66) \\
\end{array}$ & 0.09 & 63.73 \\
\hline TGROWTH & Target firm growth rate. & 386 & $\begin{array}{c}155.14 * * * \\
(540.95)\end{array}$ & -48.10 & 4576.06 \\
\hline TPROFIT & Target ROA & 389 & $\begin{array}{c}-5.66 * * * \\
(34.71)\end{array}$ & -263.76 & 48.50 \\
\hline TLEVER & Target Debt/Equity ${ }^{1}$ & 387 & $\begin{array}{l}59.75 * * * \\
(186.40)\end{array}$ & -648.68 & 2182.72 \\
\hline PCTCASH & Percent cash financing & 681 & $\begin{array}{c}38 * * * \\
(45)\end{array}$ & 0 & 100 \\
\hline ATTITUDE & $\begin{array}{l}\text { Hostile }=-1, \text { Friendly }=1 \text {, } \\
\text { Neutral }=0\end{array}$ & 669 & $\begin{array}{c}0.93^{* * * *} \\
(0.36)\end{array}$ & -1 & 1 \\
\hline COMPLETE & Completed deals $=1$ & 684 & $\begin{array}{c}0.78^{* * * *} \\
(0.41)\end{array}$ & 0 & 1 \\
\hline CROSS & 1 if non US acquirer & 684 & $\begin{array}{c}0.15^{* * * *} \\
(0.36)\end{array}$ & 0 & 1 \\
\hline RELSIZE & $\begin{array}{l}\text { Target market cap over } \\
\text { acquirer market cap }\end{array}$ & 403 & $\begin{array}{c}54.91 * * * \\
(91.89)\end{array}$ & 0.07 & 966.60 \\
\hline
\end{tabular}

Notes: $*, * *, * * *$ denotes significance at the $10 \%, 5 \%, 1 \%$ level, respectively. Standard deviations are in parentheses.

${ }^{1}$ The variable TLEVER obtained from Compustat is long-term debt divided by total common equity. Common equity is defined as common stock outstanding (including stock adjustments) + capital surplus + retained earnings + treasury stock adjustments for common and nonredeemable preferred stock. The value is negative for distressed firms (15 target firms in our sample). 
Table 3. Target and Acquirer Abnormal Returns Without Controlling for Banking Relationships

\begin{tabular}{|c|c|c|c|c|c|}
\hline \multirow{2}{*}{ Variable } & \multirow{2}{*}{ Definition } & \multicolumn{2}{|c|}{ Target $(-1,+1)$ SCAR } & \multicolumn{2}{|c|}{ Acquirer $(-1,+1)$ SCAR } \\
\hline & & (1) & (2) & (3) & (4) \\
\hline Intercept & Regression constant & $\begin{array}{c}3.1531 * * * \\
(0.4258)\end{array}$ & $\begin{array}{l}2.1163^{*} \\
(1.1027)\end{array}$ & $\begin{array}{c}-0.6028 * * * \\
(0.1614) \\
\end{array}$ & $\begin{array}{c}-1.8384 * * * \\
(0.4242) \\
\end{array}$ \\
\hline DUMBANK & $\begin{array}{l}\text { Dummy indicator for commercial } \\
\text { bank advisor }\end{array}$ & $\begin{array}{c}0.4288 \\
(0.5264)\end{array}$ & $\begin{array}{l}1.7695 * * \\
(0.7029)\end{array}$ & $\begin{array}{l}0.3639^{*} \\
(0.1942)\end{array}$ & $\begin{array}{l}-0.0465 \\
(0.2707)\end{array}$ \\
\hline MIDTIER & $\begin{array}{l}\text { Dummy indicator for mid tier } \\
\text { advisor investment banks }\end{array}$ & $\begin{array}{l}-0.5259 \\
(1.0514) \\
\end{array}$ & $\begin{array}{c}1.6054 \\
(1.3996) \\
\end{array}$ & $\begin{array}{c}0.8865 * * \\
(0.3775) \\
\end{array}$ & $\begin{array}{c}0.1666 \\
(0.5199) \\
\end{array}$ \\
\hline BVPREM & Premium over Book value & & $\begin{array}{l}-0.0586 \\
(0.0546)\end{array}$ & & $\begin{array}{l}0.0429 * * \\
(0.0200)\end{array}$ \\
\hline TGROWTH & Target firm growth rate & & $\begin{array}{l}-0.0004 \\
(0.0005) \\
\end{array}$ & & $\begin{array}{c}-0.0004 * * \\
(0.0002) \\
\end{array}$ \\
\hline TPROFIT & Target ROA & & $\begin{array}{c}0.0183 \\
(0.0121) \\
\end{array}$ & & $\begin{array}{c}-0.0089 * * \\
(0.0042) \\
\end{array}$ \\
\hline TLEVER & Target leverage & & $\begin{array}{c}0.0003 \\
(0.0020)\end{array}$ & & $\begin{array}{l}-0.0009 \\
(0.0008)\end{array}$ \\
\hline PCTCASH & Cash financing & & $\begin{array}{c}0.0292 * * * \\
(0.0071)\end{array}$ & & $\begin{array}{c}0.0099 * * * \\
(0.0027)\end{array}$ \\
\hline CROSS & Cross border & & $\begin{array}{c}0.7235 \\
(0.7780)\end{array}$ & & $\begin{array}{l}0.3103 \\
(0.4279)\end{array}$ \\
\hline ATTITUDE & Hostile-friendly & & $\begin{array}{c}0.2605 \\
(0.7028)\end{array}$ & & $\begin{array}{c}0.2710 \\
(0.2545)\end{array}$ \\
\hline COMPLETE & Indicator of deal completion & & $\begin{array}{l}-0.4077 \\
(0.8436)\end{array}$ & & $\begin{array}{c}0.1882 \\
(0.3235)\end{array}$ \\
\hline$D 95$ & Dummy for 1995 & & $\begin{array}{l}-1.1847 \\
(1.4984)\end{array}$ & & $\begin{array}{l}1.5502 * * * \\
(0.5588)\end{array}$ \\
\hline D96 & Dummy for 1996 & & $\begin{array}{l}-1.5675 \\
(1.5618)\end{array}$ & & $\begin{array}{c}1.5829 * * * \\
(0.6091)\end{array}$ \\
\hline$D 97$ & Dummy for 1997 & & $\begin{array}{l}-1.2442 \\
(0.9346)\end{array}$ & & $\begin{array}{l}0.5975^{*} \\
(0.3474)\end{array}$ \\
\hline D98 & Dummy for 1998 & & $\begin{array}{l}-0.7994 \\
(0.8455)\end{array}$ & & $\begin{array}{l}0.7572 * * \\
(0.3265)\end{array}$ \\
\hline D99 & Dummy for 1999 & & $\begin{array}{l}2.0628^{*} \\
(1.1757) \\
\end{array}$ & & $\begin{array}{l}1.0048^{* *} \\
(0.4407) \\
\end{array}$ \\
\hline $\begin{array}{l}R^{2} \\
\text { Adjusted } R^{2}\end{array}$ & & $\begin{array}{r}0.27 \% \\
-0.14 \% \\
\end{array}$ & $\begin{array}{l}13.01 \% \\
8.61 \%\end{array}$ & $\begin{array}{l}1.35 \% \\
0.95 \%\end{array}$ & $\begin{array}{l}15.94 \% \\
10.48 \%\end{array}$ \\
\hline $\begin{array}{l}\text { Number of } \\
\text { Observations }\end{array}$ & & 487 & 311 & 394 & 246 \\
\hline
\end{tabular}

Notes: $* * *, * * *$ denotes significance at the $10 \%, 5 \%$, and $1 \%$ level, respectively. Standard errors are in parentheses. 


\section{TABLE 4. Dependent Variable: Target 3-Day Abnormal Returns}

\begin{tabular}{|c|c|c|c|c|}
\hline Variable & Definition & Model (1) & Model (2) & Model (3) \\
\hline Intercept & Regression constant & $\begin{array}{c}3.1299 * * * \\
(0.4040)\end{array}$ & $\begin{array}{l}2.0783 * \\
(1.0704)\end{array}$ & $\begin{array}{c}2.8866 * * \\
(1.2735) \\
\end{array}$ \\
\hline$T B \_B T$ & Target bank is target advisor & $\begin{array}{c}1.3796 * * \\
(0.6777) \\
\end{array}$ & $\begin{array}{c}2.4130 * * * \\
(0.7931)\end{array}$ & $\begin{array}{c}2.2708 * * * \\
(0.8239) \\
\end{array}$ \\
\hline$T B \_B A$ & Acquirer bank is target advisor & $\begin{array}{l}-0.5331 \\
(0.7691) \\
\end{array}$ & $\begin{array}{l}-1.2349 \\
(0.8868) \\
\end{array}$ & $\begin{array}{l}-1.3383 \\
(0.8968) \\
\end{array}$ \\
\hline$A B \_B T$ & Target bank is acquirer advisor & $\begin{array}{l}-0.5772 \\
(0.8152) \\
\end{array}$ & $\begin{array}{l}-1.7233 * \\
(0.9461) \\
\end{array}$ & $\begin{array}{l}-1.8472 * \\
(0.9588) \\
\end{array}$ \\
\hline$A B \_B A$ & Acquirer bank is acquirer advisor & $\begin{array}{c}0.2990 \\
(0.7521)\end{array}$ & $\begin{array}{c}0.8484 \\
(0.8739)\end{array}$ & $\begin{array}{c}0.8157 \\
(0.8918)\end{array}$ \\
\hline MIDTIER & Only mid tier nonbank advisor & $\begin{array}{l}-0.5027 \\
(1.0277) \\
\end{array}$ & $\begin{array}{l}-0.0430 \\
(1.2039) \\
\end{array}$ & $\begin{array}{c}0.2202 \\
(1.2767) \\
\end{array}$ \\
\hline TOPTIER & Top tier nonbank advisor & $\begin{array}{l}-0.2545 \\
(0.5552)\end{array}$ & $\begin{array}{l}-0.7040 \\
(0.6320)\end{array}$ & $\begin{array}{l}-1.0940 \\
(0.7978)\end{array}$ \\
\hline$B V P R E M$ & Premium over Book value & & $\begin{array}{l}-0.0542 \\
(0.0566)\end{array}$ & $\begin{array}{l}-0.0509 \\
(0.0574)\end{array}$ \\
\hline TGROWTH & Target firm growth rate & & $\begin{array}{l}-0.0003 \\
(0.0005) \\
\end{array}$ & $\begin{array}{l}-0.0003 \\
(0.0005) \\
\end{array}$ \\
\hline TPROFIT & Target ROA & & $\begin{array}{c}0.0185 \\
(0.0120) \\
\end{array}$ & $\begin{array}{c}0.0185 \\
(0.0121) \\
\end{array}$ \\
\hline TLEVER & Target leverage & & $\begin{array}{c}0.0003 \\
(0.0021) \\
\end{array}$ & $\begin{array}{c}0.0007 \\
(0.0021) \\
\end{array}$ \\
\hline PCTCASH & Percentage cash financing & & $\begin{array}{c}0.0253 * * * \\
(0.0072)\end{array}$ & $\begin{array}{c}0.0253 * * * \\
(0.0073) \\
\end{array}$ \\
\hline CROSS & Cross border & & $\begin{array}{c}0.3969 \\
(0.8597) \\
\end{array}$ & $\begin{array}{c}0.2923 \\
(0.8804) \\
\end{array}$ \\
\hline ATTITUDE & Hostile-friendly & & $\begin{array}{c}0.5430 \\
(0.6840)\end{array}$ & $\begin{array}{c}0.4273 \\
(0.7172)\end{array}$ \\
\hline COMPLETE & Indicator of deal completion & & $\begin{array}{l}-0.1518 \\
(0.8141)\end{array}$ & $\begin{array}{l}-0.3076 \\
(0.8560)\end{array}$ \\
\hline D95 & Dummy for 1995 & & & $\begin{array}{l}-0.6117 \\
(1.4849) \\
\end{array}$ \\
\hline D96 & Dummy for 1996 & & & $\begin{array}{l}-1.4170 \\
(1.5458)\end{array}$ \\
\hline D97 & Dummy for 1997 & & & $\begin{array}{l}-0.6226 \\
(0.9748) \\
\end{array}$ \\
\hline D98 & Dummy for 1998 & & & $\begin{array}{l}-0.3700 \\
(0.9307)\end{array}$ \\
\hline D99 & Dummy for 1999 & & & $\begin{array}{l}-1.5446 \\
(1.2320)\end{array}$ \\
\hline $\begin{array}{l}R^{2} \\
\text { Adjusted } R^{2}\end{array}$ & & $\begin{array}{c}1.18 \% \\
(-0.14 \%)\end{array}$ & $\begin{array}{l}12.83 \% \\
(8.35 \%)\end{array}$ & $\begin{array}{l}13.55 \% \\
(7.40 \%)\end{array}$ \\
\hline $\begin{array}{l}\text { Number of } \\
\text { Observations }\end{array}$ & & 457 & 286 & 286 \\
\hline
\end{tabular}

Notes: $*, * *, * * *$ indicate significance at the $10 \%, 5 \%$, and $1 \%$ levels, respectively. Standard errors are in parentheses. 
TABLE 5. Dependent Variable: Acquirer 3-Day Abnormal Returns

\begin{tabular}{|c|c|c|c|c|}
\hline Variable & Definition & Model (1) & Model (2) & Model (3) \\
\hline Intercept & Regression constant & $\begin{array}{l}-0.7822 \\
(0.1407) \\
\end{array}$ & $\begin{array}{c}-0.9190^{* *} \\
(0.4323)\end{array}$ & $\begin{array}{c}-1.4250 * * * \\
(0.4904)\end{array}$ \\
\hline$T B \_B T$ & Target bank is target advisor & $\begin{array}{l}-0.1312 \\
(0.2550)\end{array}$ & $\begin{array}{c}-0.6348^{* *} \\
(0.3152) \\
\end{array}$ & $\begin{array}{l}-0.5641^{*} \\
(0.3237)\end{array}$ \\
\hline$T B \_B A$ & Acquirer bank is target advisor & $\begin{array}{l}-0.4058 \\
(0.2701) \\
\end{array}$ & $\begin{array}{l}-0.2457 \\
(0.3443) \\
\end{array}$ & $\begin{array}{l}-0.1412 \\
(0.3460)\end{array}$ \\
\hline$A B \_B T$ & Target bank is acquirer advisor & $\begin{array}{l}-0.2455 \\
(0.3373) \\
\end{array}$ & $\begin{array}{l}-0.2912 \\
(0.3824) \\
\end{array}$ & $\begin{array}{l}-0.2139 \\
(0.3838)\end{array}$ \\
\hline$A B \_B A$ & Acquirer bank is acquirer advisor & $\begin{array}{l}-0.0245 \\
(0.2935)\end{array}$ & $\begin{array}{l}-0.3537 \\
(0.3355)\end{array}$ & $\begin{array}{l}-0.2646 \\
(0.3419)\end{array}$ \\
\hline MIDTIER & Only mid tier nonbank advisor & $\begin{array}{c}0.3620 \\
(0.3719) \\
\end{array}$ & $\begin{array}{c}0.4139 \\
(0.4576)\end{array}$ & $\begin{array}{l}-0.0152 \\
(0.4858)\end{array}$ \\
\hline TOPTIER & Top tier nonbank advisor & $\begin{array}{l}-0.3961 * \\
(0.2060) \\
\end{array}$ & $\begin{array}{c}-0.5229 * * \\
(0.2542) \\
\end{array}$ & $\begin{array}{l}-0.2539 \\
(0.3107) \\
\end{array}$ \\
\hline ACCESS & $\begin{array}{l}\text { Acquirer's bank lends } 1 \text { year after } \\
\text { merger }\end{array}$ & $\begin{array}{l}-0.0833 \\
(0.3831)\end{array}$ & $\begin{array}{c}0.2569 \\
(0.4794)\end{array}$ & $\begin{array}{c}0.1491 \\
(0.4880) \\
\end{array}$ \\
\hline$B V P R E M$ & Premium over Book value & & $\begin{array}{c}0.0585 * * * \\
(0.0219)\end{array}$ & $\begin{array}{c}0.0581 * * * \\
(0.0220)\end{array}$ \\
\hline TGROWTH & Target firm growth rate & & $\begin{array}{c}-0.0004 * * \\
(0.0002)\end{array}$ & $\begin{array}{c}-0.0004 * * \\
(0.0002)\end{array}$ \\
\hline TPROFIT & Target ROA & & $\begin{array}{l}-0.0082^{*} \\
(0.0043)\end{array}$ & $\begin{array}{l}-0.0083^{*} \\
(0.0043)\end{array}$ \\
\hline TLEVER & Target leverage & & $\begin{array}{l}-0.0003 \\
(0.0008)\end{array}$ & $\begin{array}{l}-0.0006 \\
(0.0008)\end{array}$ \\
\hline PCTCASH & Percentage cash financing & & $\begin{array}{c}0.0107 * * * \\
(0.0029)\end{array}$ & $\begin{array}{c}0.0110^{* * * *} \\
(0.0028)\end{array}$ \\
\hline CROSS & Cross border & & $\begin{array}{c}0.5511 \\
(0.5245)\end{array}$ & $\begin{array}{c}0.6693 \\
(0.5264)\end{array}$ \\
\hline ATTITUDE & Hostile-friendly & & $\begin{array}{c}0.0214 \\
(0.2656)\end{array}$ & $\begin{array}{c}0.1500 \\
(0.2709)\end{array}$ \\
\hline COMPLETE & Indicator of deal completion & & $\begin{array}{c}0.2656 \\
(0.3297)\end{array}$ & $\begin{array}{c}0.2275 \\
(0.3366)\end{array}$ \\
\hline D95 & Dummy for 1995 & & & $\begin{array}{l}1.3831 * * \\
(0.5700)\end{array}$ \\
\hline D96 & Dummy for 1996 & & & $\begin{array}{l}1.2760 * * \\
(0.6264)\end{array}$ \\
\hline D97 & Dummy for 1997 & & & $\begin{array}{c}0.2967 \\
(0.3762) \\
\end{array}$ \\
\hline D98 & Dummy for 1998 & & & $\begin{array}{c}0.4159 \\
(0.3677) \\
\end{array}$ \\
\hline D99 & Dummy for 1999 & & & $\begin{array}{c}0.7165 \\
(0.4718) \\
\end{array}$ \\
\hline$R^{2}$ & & $2.30 \%$ & $16.08 \%$ & $19.46 \%$ \\
\hline Adjusted $R^{2}$ & & $0.85 \%$ & $10.36 \%$ & $11.97 \%$ \\
\hline $\begin{array}{l}\text { Number of } \\
\text { Observations }\end{array}$ & & 479 & 235 & 235 \\
\hline
\end{tabular}

Notes: $*, * *, * * *$ indicate significance at the $10 \%, 5 \%$, and $1 \%$ levels, respectively. Standard are errors in parentheses. 


\section{TABLE 6. Binomial Logit Model for Advisor Choice}

The dependent variable is an advisor selection indicator variable $S$ such that:

$\boldsymbol{S}=\mathbf{0}$ if the target and the acquirer use either nonbank advisors or banks with no prior relationships with either merger counterparty; and

$S=\mathbf{1}$ if either the target or the acquirer uses a bank advisor with a prior lending relationship with either the target or the acquirer.

In model (1), the independent variables are:

Lender_TBBT (Lender_ABBT) $=0$ if the target firm has no banking relationships with the target (acquirer) advisor; $=1$ if the target's bank acted as a participant in a loan syndication to the target (acquiring) firm prior to the deal announcement date; $=2$ if the target's bank acted as an agent or arranger for a loan syndication to the target (acquiring) firm prior to the deal announcement date.

Lender_TBBA (Lender_ABBA) $=0$ if the acquirer has no banking relationships with the target (acquirer) advisors; $=1$ if the acquirer's bank acted as a participant in a loan syndication to the target (acquiring) firm prior to the deal announcement date; $=2$ if the acquirer's bank acted as an agent or arranger for a loan syndication to the target (acquiring) firm prior to the deal announcement date.

Duration_TBBT (Duration_ABBT) = the length of time (in years) between the origination of the earliest loan syndication to the target by the target (acquirer) advisor.

Duration_TBBA (Duration_ABBA) = the length of time (in years) between the origination of the earliest loan syndication to the acquirer by the target (acquirer) advisor.

Purpose_TBBT (Purpose_ABBT) $=0$ if there were no prior loan syndications to the target firm involving the target (acquirer) advisor; $=1$ if the purpose of the loan syndication by the target (acquirer) advisor to the target firm was related to an acquisition; $=2$ if the purpose of the loan syndication by the target (acquirer) advisor to the target firm was for general business purposes.

Purpose_TBBT (Purpose_ABBT) $=0$ if there were no prior loan syndications to the target firm involving the target (acquirer) advisor; $=1$ if the purpose of the loan syndication by the target (acquirer) advisor to the target firm was related to an acquisition; $=2$ if the purpose of the loan syndication by the target (acquirer) advisor to the target firm was for general business purposes.

Nonadvisor Lender_T (Nonadvisor Lender_A) $=0$ if there were no loan syndications involving nonadvisors to the target (acquirer); $=1$ if the highest level of participation by any nonadvisor in a loan syndication to the target (acquirer) was as a participant; $=2$ if the highest level of participation by any nonadvisor in a loan syndication to the target (acquirer) was as an agent or arranger.

Nonadvisor Duration_T (Nonadvisor Duration_A) = the length of time between the merger

announcement date and the earliest loan syndication involving a bank that advises neither the target nor the acquirer.

Nonadvisor Purpose_T (Nonadvisor Purpose_A) $=0$ if there were no loan syndications involving nonadvisors to the target (acquirer) $;=1$ if the purpose of the loan syndication by any nonadvisor to the target (acquirer) was related to an acquisition; =2 if the purpose of the loan syndication by any nonadvisor to the target (acquirer) was for general business purposes.

Access $=1$ ( 0 otherwise) if the acquirer's bank is chosen as an advisor and subsequently lends to the acquirer up to one year after the merger announcement date. 


\section{Table 6}

\begin{tabular}{|c|c|c|}
\hline Independent Variable & Definition & Coefficients \\
\hline Intercept & Regression constant & $\begin{array}{c}-1.3423 * * * \\
(0.3421)\end{array}$ \\
\hline Lender_TBBT & $\begin{array}{l}\text { Intensity of loan syndication relationship of } \\
\text { target bank advisor with target }\end{array}$ & $\begin{array}{l}1.7868 * * * \\
(0.6154)\end{array}$ \\
\hline Lender_ABBT & $\begin{array}{l}\text { Intensity of loan syndication relationship of } \\
\text { target bank advisor with acquirer }\end{array}$ & $\begin{array}{l}1.3636 * * \\
(0.6096)\end{array}$ \\
\hline Lender_TBBA & $\begin{array}{l}\text { Intensity of loan syndication relationship of } \\
\text { acquirer bank advisor with target }\end{array}$ & $\begin{array}{l}0.9442 * \\
(0.5700)\end{array}$ \\
\hline Lender_ABBA & $\begin{array}{l}\text { Intensity of loan syndication relationship of } \\
\text { acquirer bank advisor with acquirer }\end{array}$ & $\begin{array}{l}1.2949 * * \\
(0.5103)\end{array}$ \\
\hline Duration_TBBT & $\begin{array}{l}\text { Duration of syndicated loan given by target bank } \\
\text { advisor to target }\end{array}$ & $\begin{array}{l}-0.2069 \\
(0.1492)\end{array}$ \\
\hline Duration_ABBT & $\begin{array}{l}\text { Duration of syndicated loan given by target bank } \\
\text { advisor to acquirer }\end{array}$ & $\begin{array}{l}-0.0168 \\
(0.1279)\end{array}$ \\
\hline Duration_TBBA & $\begin{array}{l}\text { Duration of syndicated loan given by acquirer } \\
\text { bank advisor to target }\end{array}$ & $\begin{array}{c}0.3273 \\
(0.2197)\end{array}$ \\
\hline Duration_ABBA & $\begin{array}{l}\text { Duration of syndicated loan given by acquirer } \\
\text { bank advisor to acquirer }\end{array}$ & $\begin{array}{l}0.2301 * * \\
(0.1048)\end{array}$ \\
\hline Purpose_TBBT & $\begin{array}{l}\text { Purpose of syndicated loan given by target bank } \\
\text { advisor to target }\end{array}$ & $\begin{array}{c}0.3371 \\
(0.6816)\end{array}$ \\
\hline Purpose_ABBT & $\begin{array}{l}\text { Purpose of syndicated loan given by target bank } \\
\text { advisor to acquirer }\end{array}$ & $\begin{array}{c}0.6672 \\
(0.7353) \\
\end{array}$ \\
\hline Purpose_TBBA & $\begin{array}{l}\text { Purpose of syndicated loan given by acquirer } \\
\text { bank advisor to target }\end{array}$ & $\begin{array}{c}0.5528 \\
(0.6943)\end{array}$ \\
\hline Purpose_ABBA & $\begin{array}{l}\text { Purpose of syndicated loan given by acquirer } \\
\text { bank advisor to acquirer }\end{array}$ & $\begin{array}{l}1.2217 * * \\
(0.6202) \\
\end{array}$ \\
\hline Access & $\begin{array}{l}\text { Acquirer's bank advisor and lends to the } \\
\text { acquirer up to one year after the merger. }\end{array}$ & $\begin{array}{l}1.3243 * * \\
(0.6578) \\
\end{array}$ \\
\hline Nonadvisor Lender_T & $\begin{array}{l}\text { Intensity of loan syndication relationship of } \\
\text { nonadvisor banks with target }\end{array}$ & $\begin{array}{l}-0.1594 \\
(0.6677)\end{array}$ \\
\hline Nonadvisor Lender_A & $\begin{array}{l}\text { Intensity of loan syndication relationship of } \\
\text { nonadvisor banks with acquirer }\end{array}$ & $\begin{array}{l}-0.6871 \\
(0.6362)\end{array}$ \\
\hline Nonadvisor Duration_T & $\begin{array}{l}\text { Duration of syndicated loan given by nonadvisor } \\
\text { banks to target }\end{array}$ & $\begin{array}{c}0.1252 \\
(0.1584) \\
\end{array}$ \\
\hline Nonadvisor Duration_A & $\begin{array}{l}\text { Duration of syndicated loan given by nonadvisor } \\
\text { banks to target }\end{array}$ & $\begin{array}{c}0.0308 \\
(0.1789)\end{array}$ \\
\hline Nonadvisor Purpose_A & $\begin{array}{l}\text { Purpose of syndicated loan given by nonadvisor } \\
\text { banks to target }\end{array}$ & $\begin{array}{c}0.2085 \\
(0.7403) \\
\end{array}$ \\
\hline Nonadvisor Purpose_A & $\begin{array}{l}\text { Purpose of syndicated loan given by nonadvisor } \\
\text { banks to acquirer }\end{array}$ & $\begin{array}{l}1.3854 * * \\
(0.6977) \\
\end{array}$ \\
\hline Number of observations & & 241 \\
\hline Concordant ratio (percent) & & 84.1 \\
\hline Likelihood ratio test & & $87.8 * * *$ \\
\hline
\end{tabular}

Notes: $*, * *, * * *$ indicate significance at the $10 \%, 5 \%$, and $1 \%$ levels, respectively. Standard errors are in parentheses. 


\section{Table 7. Bank Advisor Abnormal Returns}

The pooled return generating function was estimated for 8 bank advisors over the period January 2, 1995 through December 31, 2000 (or whatever subset of the period was relevant for each bank). Our sample of bank advisors includes Citicorp (before merger with Travelers), FleetBoston, Chase Manhattan Bank, JP Morgan Bank (before merger with Chase), Bankers Trust (before takeover by Deutschebank), BankBoston (before merger with Fleet), Bank of America (including Nationsbank), Citigroup (after merger with Travelers).

The dependent variable is the percent daily return (including dividends) on the 8 bank advisors.

The independent variables are:

$\boldsymbol{T B} \_\boldsymbol{B} \boldsymbol{T}\left(\boldsymbol{A B} \_\boldsymbol{B} \boldsymbol{T}\right)=1$ if the target's (acquirer's) advisor had a prior banking relationship with the target.

$\boldsymbol{T} \boldsymbol{B} \_\boldsymbol{B} \boldsymbol{A}\left(\boldsymbol{A} \boldsymbol{B} \_\boldsymbol{B} \boldsymbol{A}\right)=1$ if the target's (acquirer's) advisor had a prior banking relationship with the acquirer.

DTARADV $(\boldsymbol{D A C Q A D V})=1$ if the bank advised the target (acquirer) in the merger.

$M A R K E T=$ the daily CRSP equally weighted index.

EVENT PERIOD $=1$ on each day of the $(-1$, to +1$)$ event window surrounding each merger announcement.

$\boldsymbol{S I Z E}=$ the $\log$ of target's market capitalization as of the merger announcement

$\boldsymbol{A C C E S S}=1$ (0 otherwise) if the acquirer's bank is chosen as an advisor and subsequently lends to the acquirer up to one year after the merger announcement date.

$\boldsymbol{R E} \boldsymbol{L S I Z E}=$ the target's market capitalization divided by the acquirer's market capitalization as of merger announcement date (measured as a decimal).

TB_BT $\boldsymbol{x}$ DTARADV $\left(\boldsymbol{A B} \_B \boldsymbol{B} \boldsymbol{x} \boldsymbol{D A C Q A D V}\right)=1$ if the dependent bank is the target's (acquirer's) advisor and had a prior banking relationship with the target (acquirer).

TB_BA $\boldsymbol{x}$ DTARADV $\left(\boldsymbol{A B} \_B T \boldsymbol{x} \boldsymbol{D A C Q A D V}\right)=1$ if the dependent bank is the target's (acquirer's) advisor and had a prior banking relationship with the acquirer (target).

$A B \_B T x D T A R A D V\left(T B \_B A x D A C Q A D V\right)=1$ if there is a relationship between the target (acquirer) and the acquirer's (target's) advisor, but the dependent bank is the target's (acquirer's) advisor.

$A B \_B A x D T A R A D V\left(T B \_B T x D A C Q A D V\right)=1$ if there is a relationship between the acquirer (target) and the acquirer's (target's) advisor, but the dependent bank is the target's (acquirer's) advisor.

(Table 7 Continued next page) 


\section{Table 7}

\begin{tabular}{|c|c|c|c|}
\hline $\begin{array}{c}\text { Independent Variables } \\
\text { Specification (1) }\end{array}$ & $\begin{array}{c}\text { Specification } \\
(1)\end{array}$ & $\begin{array}{c}\text { Specification } \\
(2)\end{array}$ & $\begin{array}{c}\text { Independent Variables } \\
\text { Specification (2) }\end{array}$ \\
\hline Intercept & $\begin{array}{l}-0.0002 \\
(0.0002) \\
\end{array}$ & $\begin{array}{l}-0.0002 \\
(0.0002)\end{array}$ & Intercept \\
\hline$T B \_B T$ & $\begin{array}{c}0.0017 \\
(0.0026) \\
\end{array}$ & $\begin{array}{c}0.0018 \\
(0.0037) \\
\end{array}$ & $T B \_B T \times D T A R A D V$ \\
\hline$T B \_B A$ & $\begin{array}{c}0.0012 \\
(0.0029) \\
\end{array}$ & $\begin{array}{c}0.0040 \\
(0.0048) \\
\end{array}$ & $T B \_B A \times D T A R A D V$ \\
\hline$A B \_B T$ & $\begin{array}{l}-0.0004 \\
(0.0023)\end{array}$ & $\begin{array}{c}0.0017 \\
(0.0049) \\
\end{array}$ & $A B \_B T \times D T A R A D V$ \\
\hline$A B \_B A$ & $\begin{array}{c}-0.0049 * * \\
(0.0021)\end{array}$ & $\begin{array}{c}-0.0024 \\
(0.0041)\end{array}$ & $A B \_B A \times D T A R A D V$ \\
\hline DTARADV & $\begin{array}{l}-0.0002 \\
(0.0027) \\
\end{array}$ & $\begin{array}{c}0.0027 \\
(0.0031) \\
\end{array}$ & $T B \_B T \times D A C Q A D V$ \\
\hline \multirow[t]{3}{*}{$D A C Q A D V$} & $\begin{array}{c}-0.0072 * * \\
(0.0036) \\
\end{array}$ & $\begin{array}{l}-0.0005 \\
(0.0036)\end{array}$ & $T B \_B A \times D A C Q A D V$ \\
\hline & & $\begin{array}{c}-0.0018 \\
(0.0025) \\
\end{array}$ & $A B \_B T \times D A C Q A D V$ \\
\hline & & $\begin{array}{c}-0.0059 * * * \\
(0.0023)\end{array}$ & $A B \_B A \times D A C Q A D V$ \\
\hline MARKET & $\begin{array}{l}1.2862 * * * \\
(0.0244) \\
\end{array}$ & $\begin{array}{c}1.2876^{* * * *} \\
(0.0244) \\
\end{array}$ & MARKET \\
\hline EVENT PERIOD & $\begin{array}{c}0.0052 \\
(0.0040)\end{array}$ & $\begin{array}{l}-0.0008 \\
(0.0018)\end{array}$ & EVENT PERIOD \\
\hline SIZE & $\begin{array}{l}0.0003 * \\
(0.0002) \\
\end{array}$ & $\begin{array}{l}0.0003 * \\
(0.0002) \\
\end{array}$ & SIZE \\
\hline ACCESS & $\begin{array}{c}0.0036 \\
(0.0031) \\
\end{array}$ & $\begin{array}{c}0.0040 \\
(0.0032) \\
\end{array}$ & ACCESS \\
\hline RELSIZE & $\begin{array}{r}0.0005 \\
(0.0004) \\
\end{array}$ & $\begin{array}{r}0.0005 \\
(0.0004) \\
\end{array}$ & RELSIZE \\
\hline$R^{2}$ & $19.25 \%$ & $19.25 \%$ & $R^{2}$ \\
\hline Adjusted $R^{2}$ & $19.17 \%$ & $19.16 \%$ & Adjusted $R^{2}$ \\
\hline Number of Observations & 11,825 & 11,825 & Number of Observations \\
\hline
\end{tabular}

Notes: $*, * * *, * * *$ indicate significance at the $10 \%, 5 \%$, and $1 \%$ levels, respectively. Standard errors are in parentheses. 